\title{
Small Business Safety and Health Handbook
}




\section{Small Business Safety and Health Handbook}
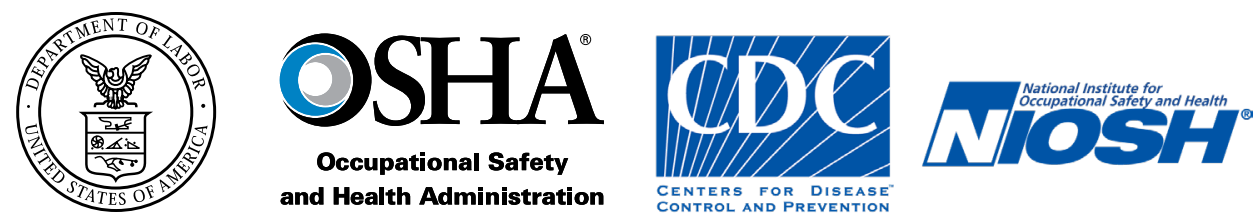


\section{Contents}

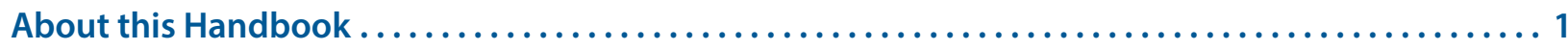

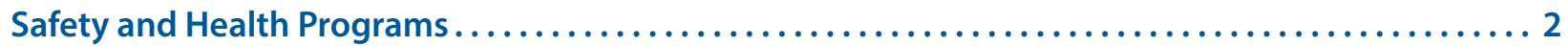

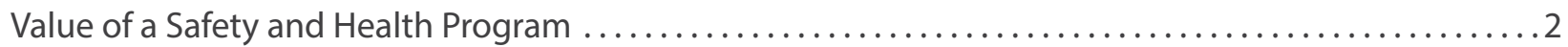

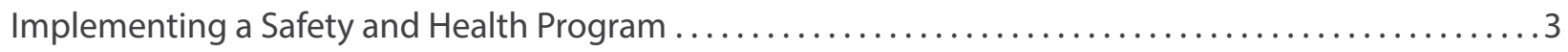

Workplace Self-Inspection. ................................................. 4

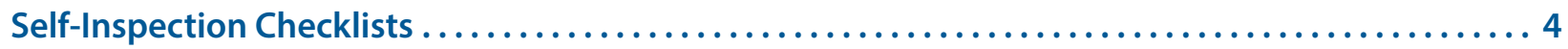

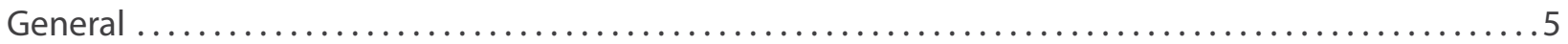

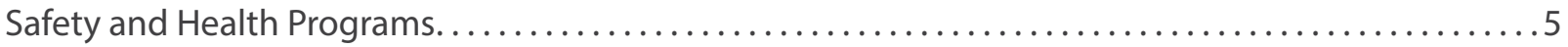

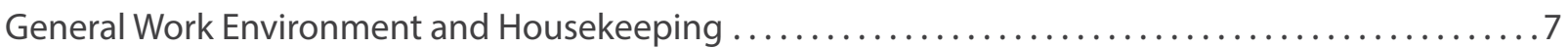

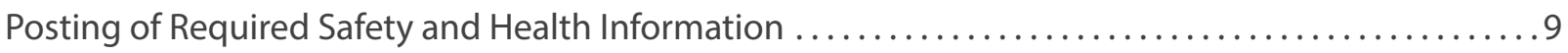

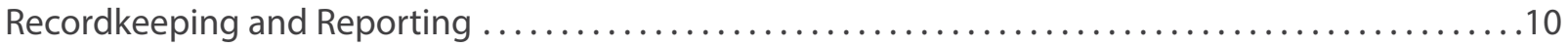

Compressed Gas Cylinders .................................................. 12

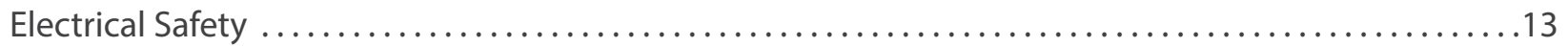

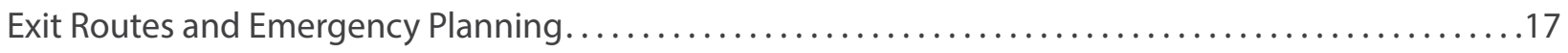

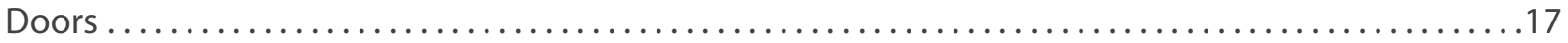

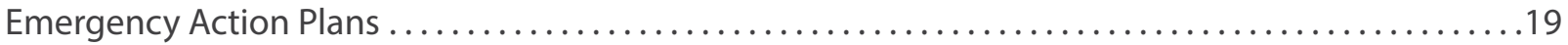

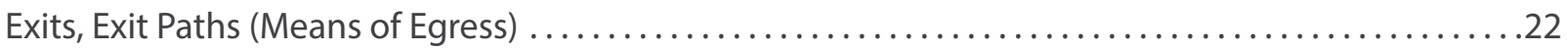

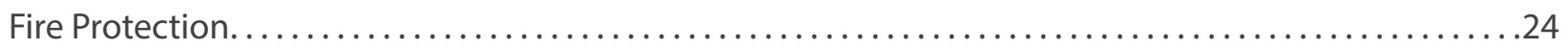

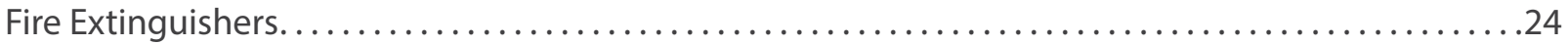

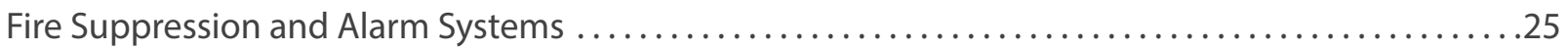

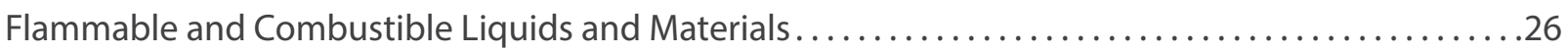

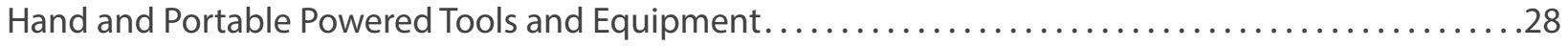

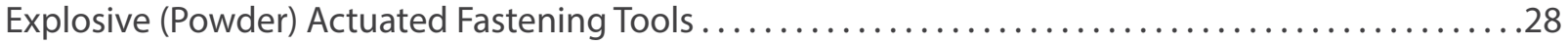

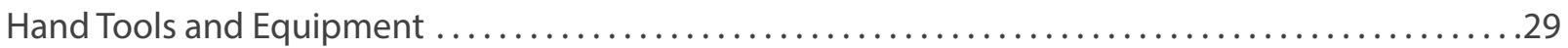

Portable (Power Operated) Tools and Equipment ................................. 31

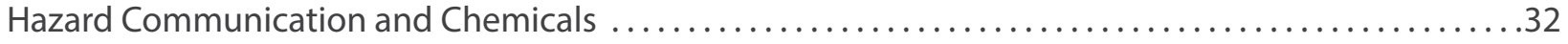

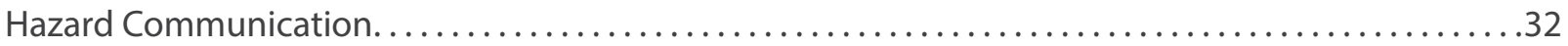

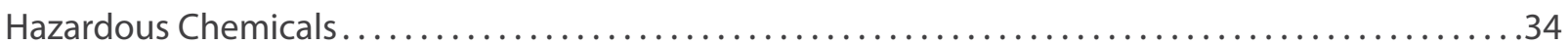




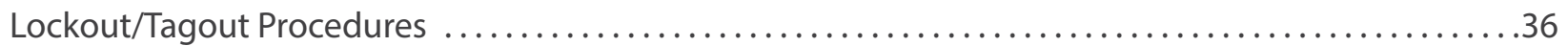

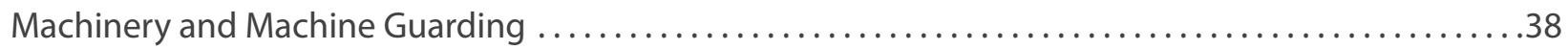

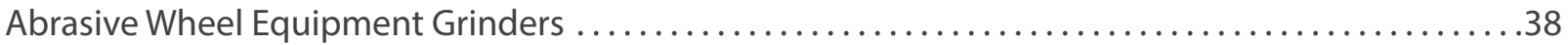

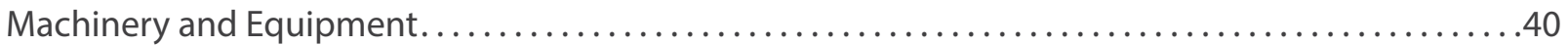

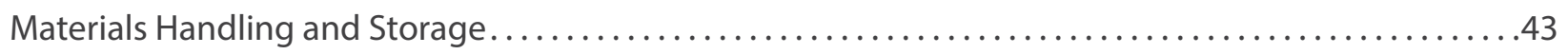

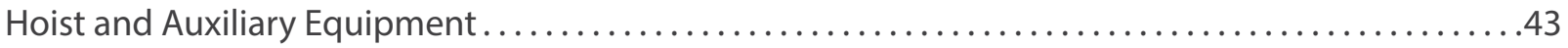

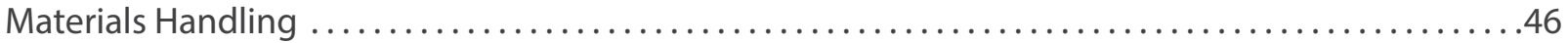

Powered Industrial Trucks................................................. 47

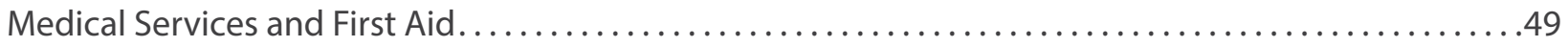

Noise Exposure ..........................................................51

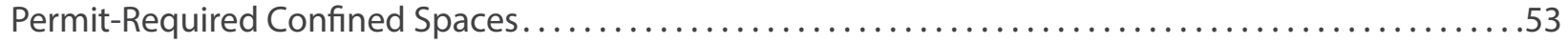

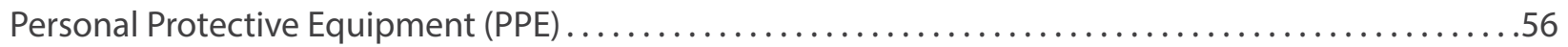

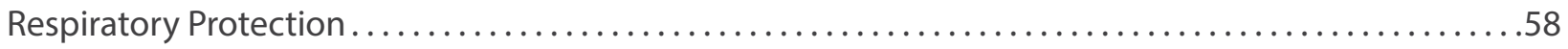

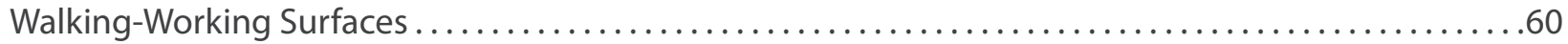

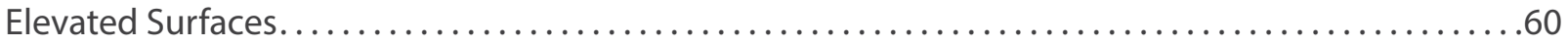

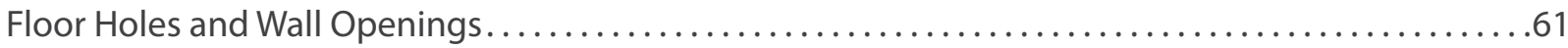

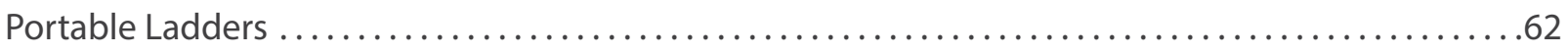

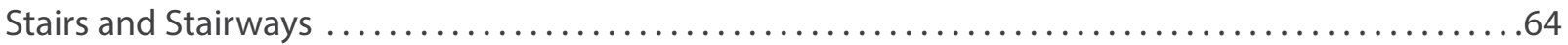

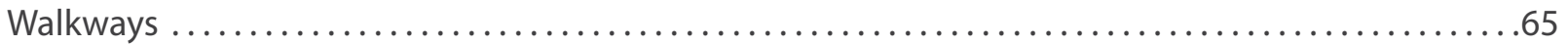

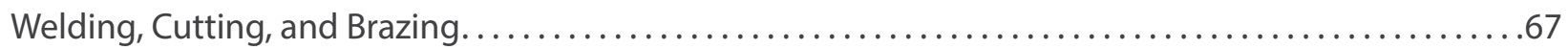

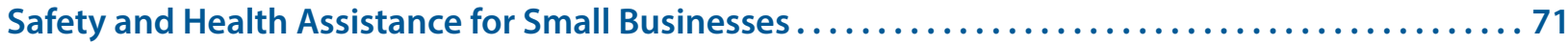

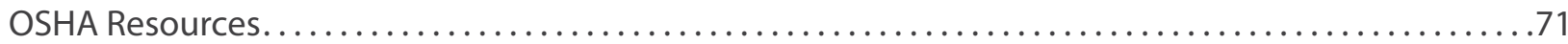

Whistleblower Program: Protection from Retaliation $\ldots \ldots \ldots \ldots \ldots \ldots \ldots \ldots \ldots \ldots \ldots \ldots \ldots \ldots \ldots \ldots$

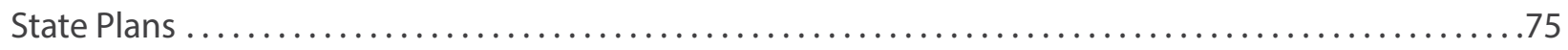

National Institute for Occupational Safety and Health (NIOSH) Resources . . . . . . . . . . . . . . ...75

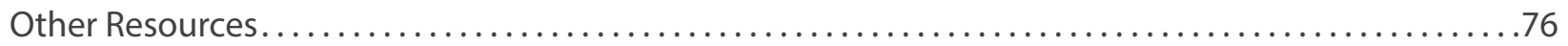

The Small Business Regulatory Enforcement Fairness Act of 1996 (SBREFA) ...................76

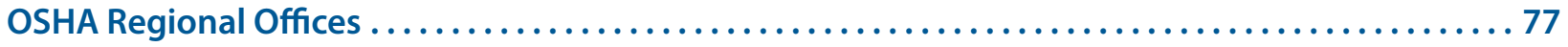

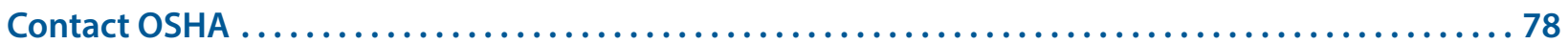




\section{About this Handbook}

The Occupational Safety and Health

Administration (OSHA) and the National Institute for Occupational Safety and Health (NIOSH) developed this handbook to provide small business employers with workplace safety and health information.

The handbook summarizes the benefits of an effective safety and health program, provides self-inspection checklists for employers to identify workplace hazards, and reviews key workplace safety and health resources for small businesses.

This handbook is a general guide. Employers should not use it to assess compliance with the Occupational Safety and Health Act of 1970 (OSH Act) or federal OSHA standards. This handbook does not provide legal interpretations of the requirements in OSHA standards, nor does it create any additional compliance requirements for employers. OSHA will not cite employers under the General Duty Clause in Section 5(a)(1) of the OSH Act for not following the handbook's recommendations.

More than 20 states and territories operate their own OSHA-approved State Plans. A list of states that operate their own State Plans can be found on OSHA's website. While the safety and health compliance requirements in these State Plans may differ in some respects from federal OSHA requirements, employers in all states may benefit from using this handbook.

This publication is in the public domain and copyright-free. You can share it, fully or partially, without permission. We appreciate, but do not require, source credit.

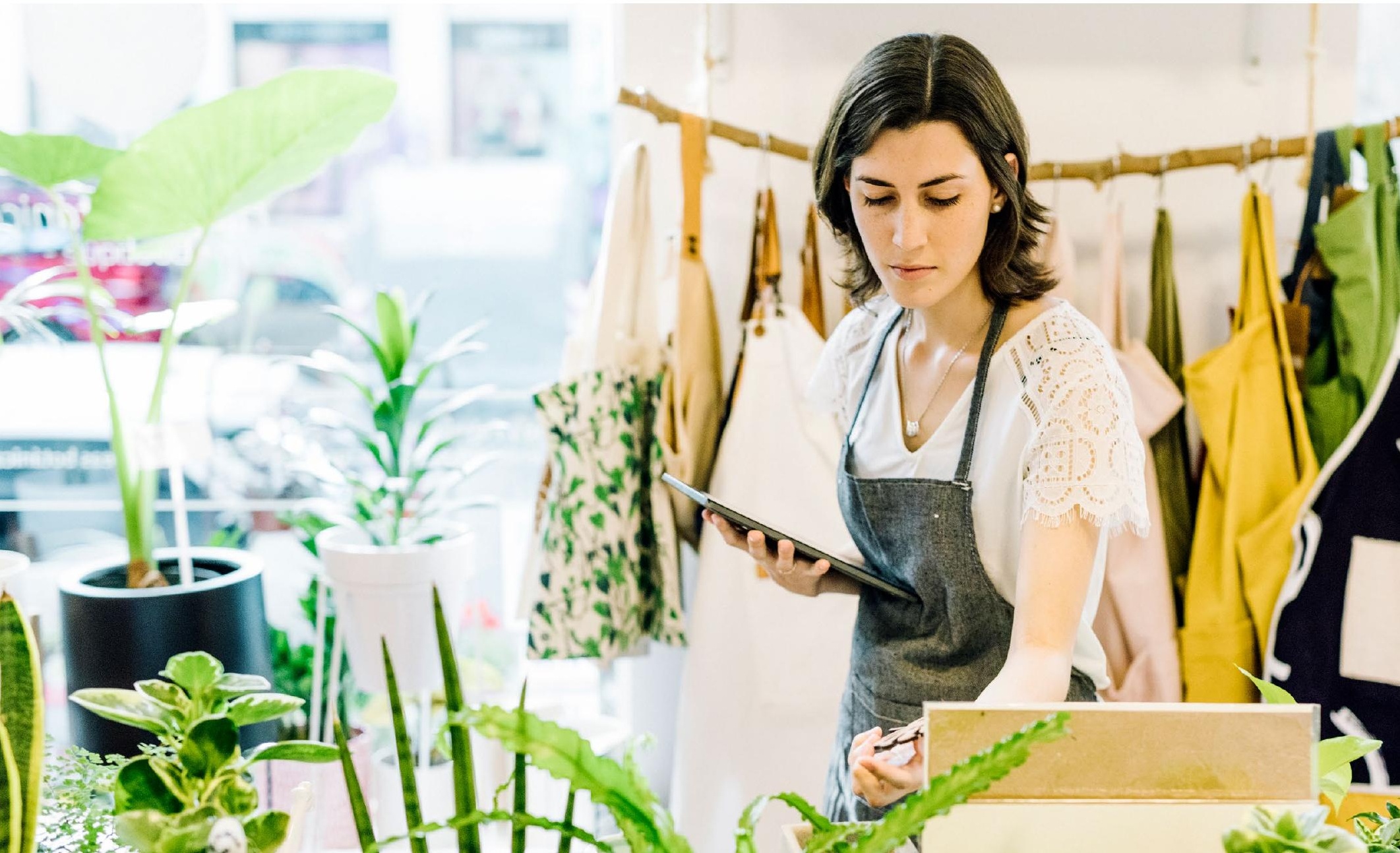




\section{Safety and Health Programs}

\section{Value of a Safety and Health Program}

Every year, more than 5,000 workers are killed on the job (average of 14 deaths per day), and more than 3.6 million suffer a serious job-related injury or illness. Even one serious workplace injury or illness can have a devastating impact on a small business, including costs associated with higher workers' compensation premiums, medical expenses, legal fees, replacement worker training, lost productivity, equipment repairs, and lower worker morale - to say nothing of the overwhelming personal impacts.

Implementing a safety and health program helps businesses:

- Prevent workplace injuries and illnesses

- Improve compliance with laws and regulations

- Reduce costs, including significant reductions in workers' compensation premiums

- Engage workers

- Enhance social responsibility goals

- Increase productivity and enhance overall business operations

Small employers like you place a high value on the well-being of your workers. Like many small businesses, you may employ family members and personal acquaintances. And, if you don't know your workers before they are hired, the size of your workplace will promote the closeness and concern for one another that small businesses value.

OSHA and NIOSH provide helpful resources and want to work with you to promote a safe and healthful workplace. Employers that make job safety and health a real part of their everyday operations will benefit in the long run. Investing in a safety and health program now will help you avoid possible losses in the future. A safe business is a sound business.

The main goal of a safety and health program is to prevent workplace injuries, illnesses, and deaths, as well as the suffering and financial hardship these events can cause for workers, their families, and employers. Traditional approaches are often reactive; that is, problems are addressed only after a worker is injured or becomes sick, a new standard or regulation is published, or an outside inspection finds a problem.

\section{OSHA's Safe + Sound campaign encourages} every workplace to have a safety and health program. Through this campaign, OSHA works with $\mathrm{NIOSH}$ and other organizations to provide resources to help employers develop safety and health programs and to recognize the successes of these programs.

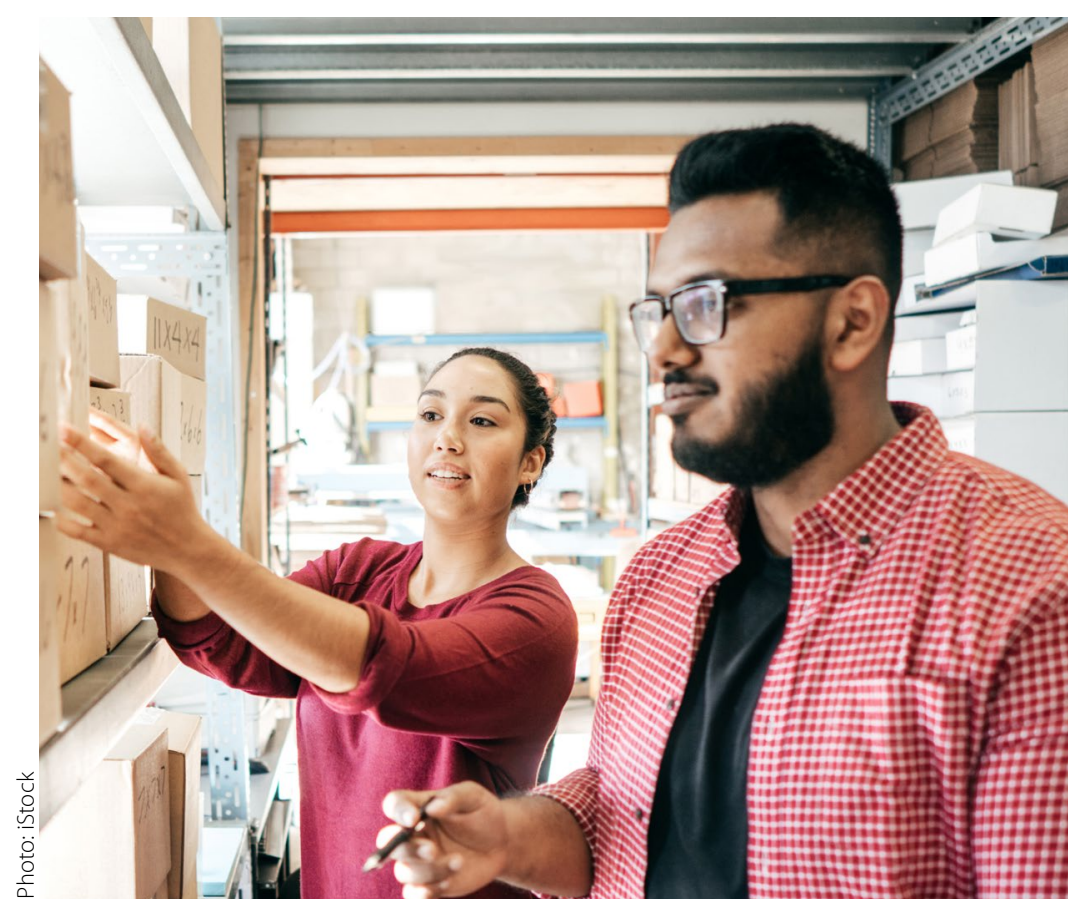




\section{Implementing a Safety and Health Program}

OSHA's Recommended Practices for Safety and Health Programs use a proactive approach to managing workplace safety and health, recognizing that finding and fixing hazards before they cause injury or illness is a far more effective approach. The Recommended Practices present a step-by-step approach to implementing a successful safety and health program, built around seven core elements:

- Management leadership

- Worker participation

- Hazard identification and assessment

- Hazard prevention and control

- Education and training

- Program evaluation and improvement

- Communication and coordination for host employers, contractors, and staffing agencies

OSHA's website includes tools to help employers implement safety and health programs, including:

- how to get started,

- a safety and health program self-evaluation tool,

- a safety and health program implementation checklist, and

- a safety and health program audit tool.

You can begin with a basic program, set simple goals, and grow from there. If you focus on achieving goals, monitoring performance, and evaluating outcomes, your workplace can progress to higher levels of safety and health achievement.

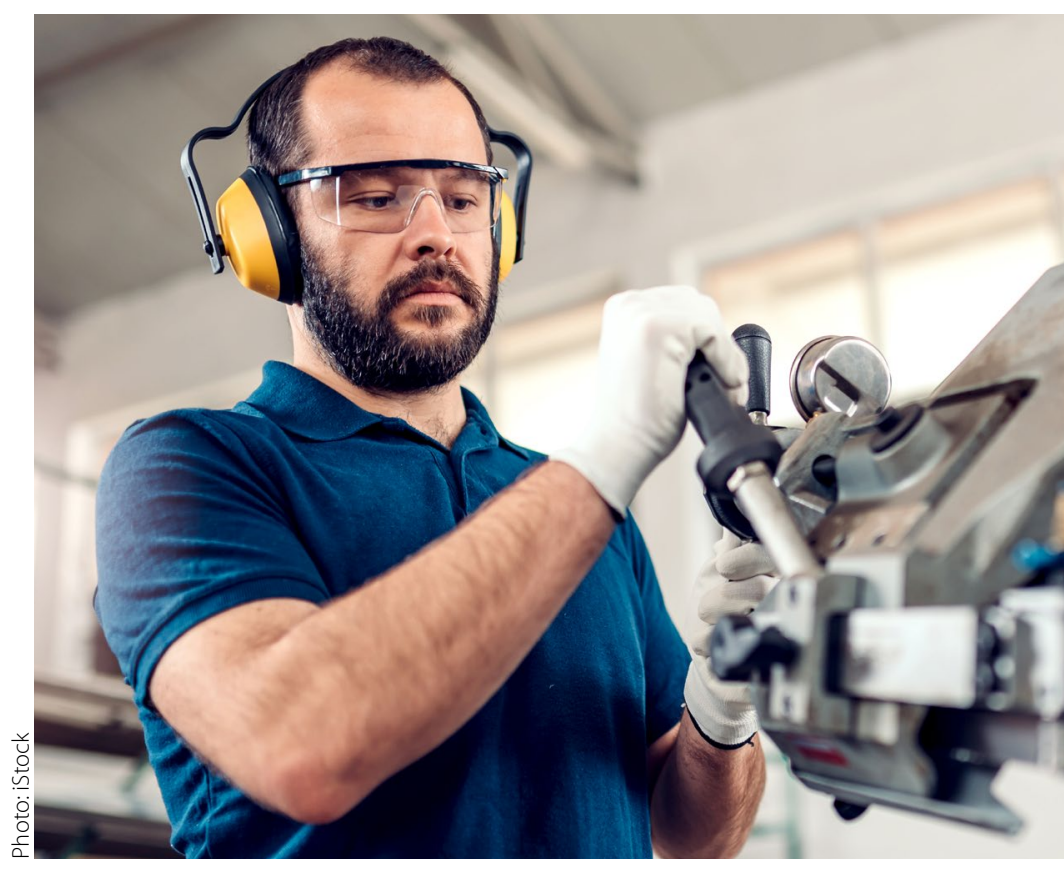

By developing and implementing a safety and health program, you are expressing and documenting your good faith and commitment to protecting your workers' health and safety. Doing so does not usually require additional workers or high costs. You can integrate safety and health into your other business functions with modest effort.

The key to a successful safety and health program is to see it as a part of your day-to-day business operation. As you incorporate it into your business culture, safety and health awareness will become second nature to you and your workers, leading to a safe and sound business.

Every workplace should have a safety and health program that includes management leadership, worker participation, and a systematic approach to finding and fixing hazards. Regular workplace inspections are an important tool for identifying hazards and fixing them. 


\section{Workplace Self-Inspection}

An effective way to identify workplace hazards is for knowledgeable and experienced workers to conduct routine safety and health inspections (i.e., self-inspections). The only way to know if potential hazards exist and if they are under control is to assess work processes directly.

Small business employers should conduct routine workplace self-inspections to:
- identify hazards,

- control identified hazards, and

- monitor and evaluate hazard controls to verify that they continue to be effective.

Consultants from OSHA's On-Site Consultation programs in all states, the District of Columbia and most territories can help small business employers with this process at no cost.

\section{Self-Inspection Checklists}

The checklists in the handbook are intended for general industry workplaces, but not for construction or maritime industries. They are a starting point for identifying workplace hazards. The checklists can give you some indication of where to begin taking action to make your business safer and more healthful for your workers. The checklists are based on several sources, including OSHA standards and generally accepted safety and health principles. Do not use the checklists to assess your compliance with the OSH Act or OSHA standards.

Compile information from your completed checklists with workplace injury and illness records, worker training information, and process and equipment information (e.g., maintenance logs, failure incident reports) to help you determine where challenges exist. Refer to OSHA standards, resources on the OSHA website, and other resources listed in this handbook to find solutions to those challenges. At the end of each checklist, you will find a link to additional resources on that topic.

\section{These checklists are not all-inclusive and not all of the checklists will apply to your}

business. You might want to start by selecting the checklists that apply to areas that are most critical to your business, then expanding your checklists over time to cover all areas that pertain to your business. Consider adding or deleting items from a checklist to more accurately cover your work processes.

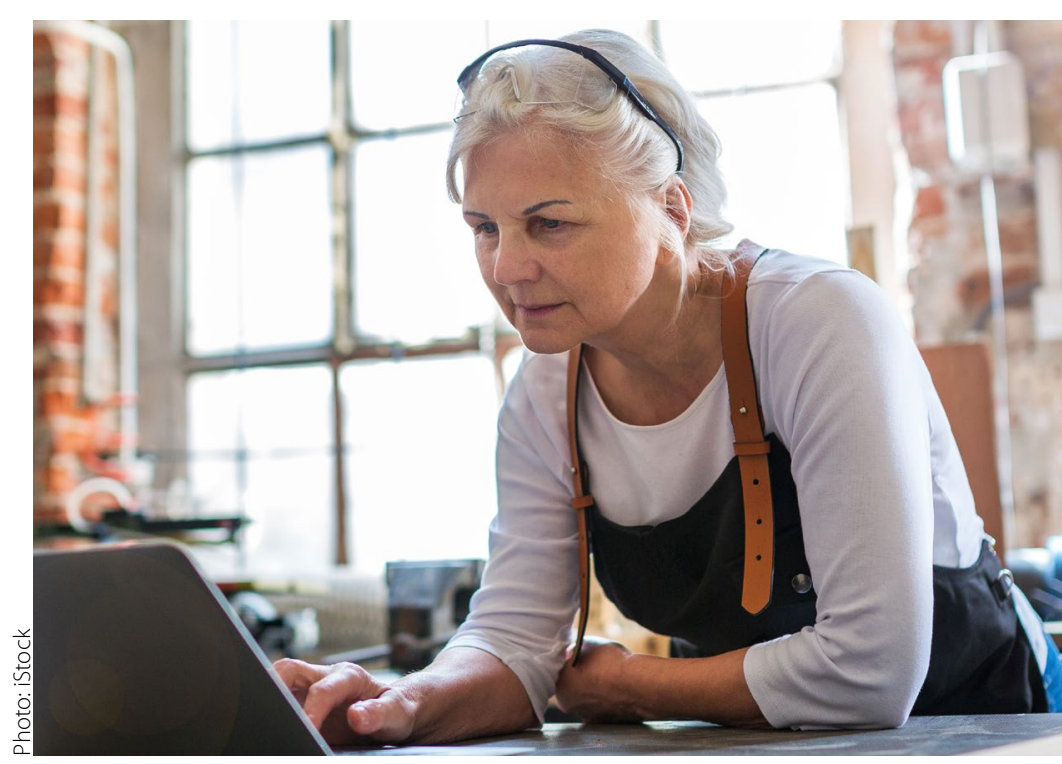


Company name:

Worksite:

Specific worksite area:

Inspected by:

Date:

\section{General}

\begin{tabular}{|c|c|c|c|c|}
\hline Safety and Health Programs & Yes & No & N/A & Comments \\
\hline $\begin{array}{l}\text { A safety and health program is in place to } \\
\text { help proactively manage safety and health in } \\
\text { the workplace. }\end{array}$ & $\square$ & $\square$ & $\square$ & \\
\hline Safety and health is a top priority. & $\square$ & $\square$ & $\square$ & \\
\hline $\begin{array}{l}\text { Safety and health is a part of daily } \\
\text { conversations with workers. }\end{array}$ & $\square$ & $\square$ & $\square$ & \\
\hline $\begin{array}{l}\text { A procedure is in place for workers to report } \\
\text { injuries, illnesses, incidents (including near } \\
\text { misses/close calls), hazards, and safety and } \\
\text { health concerns. }\end{array}$ & $\square$ & $\square$ & $\square$ & \\
\hline $\begin{array}{l}\text { Workers are trained how to identify and } \\
\text { control hazards. }\end{array}$ & $\square$ & $\square$ & $\square$ & \\
\hline $\begin{array}{l}\text { Workplace inspections are conducted } \\
\text { with workers. }\end{array}$ & $\square$ & $\square$ & $\square$ & \\
\hline $\begin{array}{l}\text { Workers are asked for ideas on } \\
\text { hazard control. }\end{array}$ & $\square$ & $\square$ & $\square$ & \\
\hline $\begin{array}{l}\text { Workers are assigned the task of choosing, } \\
\text { implementing, and evaluating hazard } \\
\text { controls they come up with. }\end{array}$ & $\square$ & $\square$ & $\square$ & \\
\hline
\end{tabular}




\begin{tabular}{|l|l|l|l|l|}
\hline Safety and Health Programs & Yes & No & N/A & Comments \\
\hline $\begin{array}{l}\text { Foreseeable emergency scenarios are } \\
\text { identified and instructions are developed } \\
\text { on what to do in each case. }\end{array}$ & $\square$ & $\square$ & $\square$ & $\square$ \\
\hline $\begin{array}{l}\text { Workers are consulted before significant } \\
\text { changes are made to the workplace, work } \\
\text { organization, equipment, or materials in order } \\
\text { to identify potential safety or health issues. }\end{array}$ & $\square$ & $\square$ & $\square$ & \\
\hline $\begin{array}{l}\text { Time is set aside to discuss safety and health } \\
\text { issues, with the goal of identifying ways to } \\
\text { improve the safety and health program. }\end{array}$ & $\square$ & $\square$ & $\square$ & \\
\hline
\end{tabular}

\section{Additional Resources}

- OSHA: Recommended Practices for Safety and Health Programs

- OSHA: \$afety Pays Program

- American Society of Safety Professionals: Guidance Manual - Keep Your People Safe in Smaller Organizations (GM-Z10.101) 


\begin{tabular}{|c|c|c|c|c|}
\hline $\begin{array}{l}\text { General Work Environment } \\
\text { and Housekeeping }\end{array}$ & Yes & No & N/A & Comments \\
\hline The workplace is clean, orderly, and sanitary. & $\square$ & $\square$ & $\square$ & \\
\hline $\begin{array}{l}\text { Workplace floors are maintained in a } \\
\text { dry condition. }\end{array}$ & $\square$ & $\square$ & $\square$ & \\
\hline $\begin{array}{l}\text { Where wet processes are used, drainage } \\
\text { is maintained and false floors, platforms, } \\
\text { mats, or other dry standing places are } \\
\text { provided, where practicable, or workers use } \\
\text { appropriate footwear. }\end{array}$ & $\square$ & $\square$ & $\square$ & \\
\hline $\begin{array}{l}\text { Enclosed workplaces are maintained to } \\
\text { prevent the entrance or harborage of rodents, } \\
\text { insects, and other vermin; and a continuing } \\
\text { and effective extermination program is } \\
\text { instituted where their presence is detected. }\end{array}$ & $\square$ & $\square$ & $\square$ & \\
\hline $\begin{array}{l}\text { Workers do not eat or drink in any areas } \\
\text { where hazardous substances are present. }\end{array}$ & $\square$ & $\square$ & $\square$ & \\
\hline $\begin{array}{l}\text { Combustible scrap, debris, and waste are } \\
\text { stored properly and promptly removed from } \\
\text { the workplace. }\end{array}$ & $\square$ & $\square$ & $\square$ & \\
\hline $\begin{array}{l}\text { Covered metal waste cans are used for rags } \\
\text { soaked in oil, flammable/combustible liquid, } \\
\text { paint, etc. }\end{array}$ & $\square$ & $\square$ & $\square$ & \\
\hline $\begin{array}{l}\text { Vacuuming and non-vigorous sweeping } \\
\text { are used in place of blowing down with } \\
\text { compressed air. }\end{array}$ & $\square$ & $\square$ & $\square$ & \\
\hline $\begin{array}{l}\text { When it is necessary to blow down in place } \\
\text { of vacuuming and sweeping, compressed air } \\
\text { pressure is limited to } 30 \text { psi, and dust clouds } \\
\text { are kept to a minimum. }\end{array}$ & $\square$ & $\square$ & $\square$ & \\
\hline
\end{tabular}




\begin{tabular}{|l|l|l|l|l|}
\hline $\begin{array}{l}\text { General Work Environment } \\
\text { and Housekeeping }\end{array}$ & Yes & No & N/A & Comments \\
\hline $\begin{array}{l}\text { General dilution or local exhaust ventilation } \\
\text { systems are used to control dusts, vapors, } \\
\text { gases, fumes, smoke, solvents, or mists } \\
\text { generated in the workplace, where possible. }\end{array}$ & $\square$ & $\square$ & $\square$ & \\
\hline $\begin{array}{l}\text { Clear space is maintained in front of electrical } \\
\text { panels; minimum } 3 \text { feet in front, and at least the } \\
\text { width of the panel, but not less than 2 } 1 / 2 \text { feet. }\end{array}$ & $\square$ & $\square$ & $\square$ & \\
\hline $\begin{array}{l}\text { Appropriate precautions are taken to maintain } \\
\text { exits, and protect workers during construction, } \\
\text { renovation, and repair operations. }\end{array}$ & $\square$ & $\square$ & $\square$ & \\
\hline
\end{tabular}

\section{Additional Resources}

- OSHA Regulations:

- 29 CFR 1910.22, General Requirements for Walking and Working Surfaces

- 29 CFR 1910.36, Design and Construction Requirements for Exit Routes

- 29 CFR 1910.37, Maintenance, Safeguards, and Operational Features for Exit Routes

- 29 CFR 1910.141, Sanitation

- OSHA: Restrooms and Sanitation Requirements

- OSHA: Indoor Air Quality

- NIOSH: Indoor Environmental Quality

- NIOSH: Office Environment 


\begin{tabular}{|c|c|c|c|c|}
\hline $\begin{array}{l}\text { Posting of Required Safety and } \\
\text { Health Information }\end{array}$ & Yes & No & $\mathbf{N} / \mathbf{A}$ & Comments \\
\hline $\begin{array}{l}\text { The required OSHA Job Safety and Health } \\
\text { Poster (or state plan equivalent) is posted in a } \\
\text { prominent location in the workplace. } \\
\text { NOTE: The poster is available for free from } \\
\text { OSHA in multiple languages. While OSHA } \\
\text { does not require employers to display } \\
\text { the poster in other languages, OSHA } \\
\text { encourages employers with employees that } \\
\text { speak other languages to also display the } \\
\text { poster in those languages. }\end{array}$ & $\square$ & $\square$ & $\square$ & \\
\hline $\begin{array}{l}\text { The annual Summary of Work-Related } \\
\text { Injuries and Illnesses (OSHA Form 300A) } \\
\text { is posted during the months of February, } \\
\text { March, and April. }\end{array}$ & $\square$ & $\square$ & $\square$ & \\
\hline $\begin{array}{l}\text { Any citations resulting from OSHA workplace } \\
\text { inspections are posted until the violation } \\
\text { has been abated, or for three working days, } \\
\text { whichever is later. }\end{array}$ & $\square$ & $\square$ & $\square$ & \\
\hline $\begin{array}{l}\text { Emergency telephone numbers are } \\
\text { posted where they can be readily found } \\
\text { in case of emergency. }\end{array}$ & $\square$ & $\square$ & $\square$ & \\
\hline
\end{tabular}

\section{Additional Resources}

- OSHA Regulations:

- 29 CFR 1903.2, Posting of OSHA Notice

- 29 CFR 1903.16, Posting of Citations

- OSHA: Free Workplace Poster - Job Safety and Health - It's the Law! 


\begin{tabular}{|c|c|c|c|c|}
\hline Recordkeeping and Reporting & Yes & No & $\mathbf{N} / \mathbf{A}$ & Comments \\
\hline $\begin{array}{l}\text { Occupational injuries or illnesses, except } \\
\text { minor injuries requiring only first aid, } \\
\text { are recorded on OSHA Form } 300 \text { (Log of } \\
\text { Work-Related Injuries and Illnesses). } \\
\text { NOTE: Employers are partially exempt from } \\
\text { OSHA's injury and illness recordkeeping } \\
\text { requirements if 1) they had } 10 \text { or fewer } \\
\text { workers during all of the last calendar } \\
\text { year (see } 29 \text { CFR 1904.1), or 2) they are in } \\
\text { certain low-hazard industries (see } 29 \text { CFR } \\
\text { Part 1904, Subpart B, Appendix A). All } \\
\text { employers, regardless of size or industry, } \\
\text { must report work-related fatalities, in-patient } \\
\text { hospitalizations, amputations, and loss of an } \\
\text { eye to OSHA. }\end{array}$ & $\square$ & $\square$ & $\square$ & \\
\hline $\begin{array}{l}\text { A supplementary record of each recordable } \\
\text { occupational injury and illness is prepared for } \\
\text { recordable cases on OSHA Form } 301 \text { (Injury } \\
\text { and Illness Incident Report). Employers can } \\
\text { use equivalent forms that provide all the } \\
\text { information on the OSHA Form } 301 \text {. }\end{array}$ & $\square$ & $\square$ & $\square$ & \\
\hline $\begin{array}{l}\text { An annual summary is prepared at the end } \\
\text { of each calendar year using OSHA Form } \\
300 A \text { (Summary of Work-Related Injuries } \\
\text { and IIInesses). }\end{array}$ & $\square$ & $\square$ & $\square$ & \\
\hline $\begin{array}{l}\text { You must electronically submit information } \\
\text { from your Form } 300 \mathrm{~A} \text { Summary to OSHA } \\
\text { annually (by March } 2 \text { of the year after the } \\
\text { calendar year covered by the form) if: } \\
\text { - You have an establishment with } 250 \text { or } \\
\text { more workers that is currently required to } \\
\text { keep OSHA injury and illness records, or } \\
\text { - You have an establishment with 20- } \\
249 \text { workers that is classified in certain } \\
\text { industries with historically high rates of } \\
\text { occupational injuries and illnesses. }\end{array}$ & $\square$ & $\square$ & $\square$ & \\
\hline
\end{tabular}




\begin{tabular}{|c|c|c|c|c|}
\hline Recordkeeping and Reporting & Yes & No & N/A & Comments \\
\hline $\begin{array}{l}\text { Injury and illness records (OSHA 300, 300A, } \\
\text { and 301) are kept at the worksite for at least } \\
\text { five years. }\end{array}$ & $\square$ & $\square$ & $\square$ & \\
\hline $\begin{array}{l}\text { Worker medical and exposure records are } \\
\text { retained for the time period required for each } \\
\text { specific type of record. }\end{array}$ & $\square$ & $\square$ & $\square$ & \\
\hline $\begin{array}{l}\text { Worker training records are kept and } \\
\text { accessible for review by workers, as required } \\
\text { by OSHA standards. }\end{array}$ & $\square$ & $\square$ & $\square$ & \\
\hline $\begin{array}{l}\text { All work-related fatalities are reported } \\
\text { to OSHA within } 8 \text { hours. All work-related } \\
\text { in-patient hospitalizations, amputations, } \\
\text { and loss of an eye are reported to OSHA } \\
\text { within } 24 \text { hours. }\end{array}$ & $\square$ & $\square$ & $\square$ & \\
\hline
\end{tabular}

\section{Additional Resources}

- OSHA Regulations:

- 29 CFR 1904, Recording and Reporting Occupational Injuries and Illness

- 29 CFR 1910.1020, Access to Employee Exposure and Medical Records

- OSHA: Injury and IIIness Recordkeeping and Reporting Requirements

- OSHA: Report a Fatality or Severe Injury

- OSHA: Access to Medical and Exposure Records 


\section{Compressed Gas Cylinders}

\begin{tabular}{|c|c|c|c|c|}
\hline Compressed Gas Cylinders & Yes & No & N/A & Comments \\
\hline $\begin{array}{l}\text { Cylinders are clearly marked to identify } \\
\text { their contents. }\end{array}$ & $\square$ & $\square$ & $\square$ & \\
\hline $\begin{array}{l}\text { Cylinders are stored where they cannot } \\
\text { be damaged by passing or falling } \\
\text { objects, and not subject to tampering by } \\
\text { unauthorized persons. }\end{array}$ & $\square$ & $\square$ & $\square$ & \\
\hline $\begin{array}{l}\text { Cylinders are regularly examined for obvious } \\
\text { signs of defects, deep rusting, and leakage. }\end{array}$ & $\square$ & $\square$ & $\square$ & \\
\hline $\begin{array}{l}\text { Care is used in handling and storage of } \\
\text { cylinders, safety valves, relief valves, etc., } \\
\text { to prevent damage. }\end{array}$ & $\square$ & $\square$ & $\square$ & \\
\hline Care is taken to not drop or strike cylinders. & $\square$ & $\square$ & $\square$ & \\
\hline $\begin{array}{l}\text { Cylinders without fixed wheels have keys, } \\
\text { handles, or non-adjustable wrenches on } \\
\text { stem valves when in service. }\end{array}$ & $\square$ & $\square$ & $\square$ & \\
\hline $\begin{array}{l}\text { Liquefied gases are stored and shipped valve- } \\
\text { end up with valve-protection caps in place. }\end{array}$ & $\square$ & $\square$ & $\square$ & \\
\hline $\begin{array}{l}\text { Valve-protection caps are placed on } \\
\text { cylinders when the cylinders are not in use, } \\
\text { or connected for use. }\end{array}$ & $\square$ & $\square$ & $\square$ & \\
\hline $\begin{array}{l}\text { Valves are closed before cylinders are } \\
\text { moved, when cylinders are empty, and at } \\
\text { the completion of each job. }\end{array}$ & $\square$ & $\square$ & $\square$ & \\
\hline $\begin{array}{l}\text { Empty cylinders are appropriately marked } \\
\text { and their valves are closed. }\end{array}$ & $\square$ & $\square$ & $\square$ & \\
\hline
\end{tabular}

\section{Additional Resources}

- OSHA Regulations:

- 29 CFR 1910.101, Compressed Gases

- 29 CFR 1910.110, Storage and Handling of Liquid Petroleum Gases

- OSHA: Compressed Gas and Equipment 


\section{Electrical Safety}

\begin{tabular}{|c|c|c|c|c|}
\hline Electrical Safety & Yes & No & N/A & Comments \\
\hline $\begin{array}{l}\text { Electrical work performed by workers or } \\
\text { contractors complies with OSHA standards. }\end{array}$ & $\square$ & $\square$ & $\square$ & \\
\hline $\begin{array}{l}\text { Sufficient access and working space is } \\
\text { provided and maintained around all } \\
\text { electrical equipment to permit ready and } \\
\text { safe operations and maintenance. }\end{array}$ & $\square$ & $\square$ & $\square$ & \\
\hline $\begin{array}{l}\text { Workers make preliminary inspections and } \\
\text { perform appropriate tests to determine } \\
\text { conditions before starting work on electrical } \\
\text { equipment or lines. }\end{array}$ & $\square$ & $\square$ & $\square$ & \\
\hline $\begin{array}{l}\text { In wet or damp locations, electrical tools and } \\
\text { equipment are appropriate for the use or } \\
\text { location or otherwise protected. }\end{array}$ & $\square$ & $\square$ & $\square$ & \\
\hline $\begin{array}{l}\text { Metal measuring tapes, ropes, hand-lines and } \\
\text { similar devices with metallic thread woven } \\
\text { into the fabric are not used where they could } \\
\text { come in contact with energized parts of } \\
\text { equipment or circuit conductors. }\end{array}$ & $\square$ & $\square$ & $\square$ & \\
\hline $\begin{array}{l}\text { Portable ladders with nonconductive side } \\
\text { rails are used where the worker or the ladder } \\
\text { could contact exposed energized parts of } \\
\text { equipment, fixtures, or circuit conductors. }\end{array}$ & $\square$ & $\square$ & $\square$ & \\
\hline $\begin{array}{l}\text { Disconnecting switches and circuit } \\
\text { breakers are labeled to indicate their use or } \\
\text { equipment served. }\end{array}$ & $\square$ & $\square$ & $\square$ & \\
\hline $\begin{array}{l}\text { Electrical installations are approved not } \\
\text { only for the class of location, but also for the } \\
\text { ignitable or combustible properties of the } \\
\text { specific gas, vapor, dust, or fiber that may } \\
\text { be present. }\end{array}$ & $\square$ & $\square$ & $\square$ & \\
\hline
\end{tabular}




\begin{tabular}{|c|c|c|c|c|}
\hline Electrical Safety & Yes & No & N/A & Comments \\
\hline $\begin{array}{l}\text { Whenever a worker is exposed to contact } \\
\text { with parts of fixed electric equipment or } \\
\text { circuits that have been de-energized, the } \\
\text { circuits energizing the parts are locked out or } \\
\text { tagged, as appropriate. }\end{array}$ & $\square$ & $\square$ & $\square$ & \\
\hline $\begin{array}{l}\text { Workers who regularly work on or around } \\
\text { energized electrical equipment or lines } \\
\text { are instructed in cardiopulmonary } \\
\text { resuscitation (CPR). }\end{array}$ & $\square$ & $\square$ & $\square$ & \\
\hline $\begin{array}{l}\text { Workers do not work alone on energized } \\
\text { lines or equipment over } 600 \text { volts. }\end{array}$ & $\square$ & $\square$ & $\square$ & \\
\hline $\begin{array}{l}\text { Barricades and safety signs are used to } \\
\text { prevent or limit access to areas where } \\
\text { workers could be exposed to uninsulated } \\
\text { energized conductors or circuit parts. }\end{array}$ & $\square$ & $\square$ & $\square$ & \\
\hline $\begin{array}{l}\text { Cord-connected, electrically operated tools } \\
\text { and equipment are effectively grounded or } \\
\text { of the approved double insulated type. }\end{array}$ & $\square$ & $\square$ & $\square$ & \\
\hline $\begin{array}{l}\text { Flexible cord sets (extensions cords) used } \\
\text { with grounding-type equipment have } \\
\text { grounding conductors. }\end{array}$ & $\square$ & $\square$ & $\square$ & \\
\hline $\begin{array}{l}\text { Cord-connected, electrically operated } \\
\text { equipment, and flexible cord sets (extension } \\
\text { cords) are visually inspected before use } \\
\text { for external defects (such as loose parts, } \\
\text { deformed and missing pins, or damage to } \\
\text { outer jacket or insulation) and for evidence of } \\
\text { possible internal damage (such as pinched or } \\
\text { crushed outer jacket). }\end{array}$ & $\square$ & $\square$ & $\square$ & \\
\hline $\begin{array}{l}\text { Exposed wiring, and cords with frayed or } \\
\text { deteriorated insulation, are immediately } \\
\text { removed from service. }\end{array}$ & $\square$ & $\square$ & $\square$ & \\
\hline
\end{tabular}




\begin{tabular}{|c|c|c|c|c|}
\hline Electrical Safety & Yes & No & N/A & Comments \\
\hline $\begin{array}{l}\text { Flexible cords are only used in continuous } \\
\text { lengths without splice or tap. }\end{array}$ & $\square$ & $\square$ & $\square$ & \\
\hline Multiple plug adaptors are not used. & $\square$ & $\square$ & $\square$ & \\
\hline $\begin{array}{l}\text { Electrical appliances such as vacuum } \\
\text { cleaners, polishers, vending machines, etc., } \\
\text { are grounded. }\end{array}$ & $\square$ & $\square$ & $\square$ & \\
\hline $\begin{array}{l}\text { Non-grounding type receptacles and } \\
\text { connectors are not used for grounding-type } \\
\text { attachment plugs. }\end{array}$ & $\square$ & $\square$ & $\square$ & \\
\hline $\begin{array}{l}\text { Ground-fault circuit interrupters are installed } \\
\text { on each temporary } 15 \text { or } 20 \text { ampere, } \\
120 \text { volt alternating current (AC) circuit at } \\
\text { locations where construction, demolition, } \\
\text { modifications, alterations, etc., are performed. }\end{array}$ & $\square$ & $\square$ & $\square$ & \\
\hline $\begin{array}{l}\text { Metal cable trays, metal raceways, and metal } \\
\text { enclosures for conductors are grounded. }\end{array}$ & $\square$ & $\square$ & $\square$ & \\
\hline $\begin{array}{l}\text { Disconnecting means are always opened } \\
\text { before fuses are replaced. }\end{array}$ & $\square$ & $\square$ & $\square$ & \\
\hline $\begin{array}{l}\text { Flexible cords and cables are connected to } \\
\text { devices and fittings so that strain relief is } \\
\text { provided to prevent pull from being directly } \\
\text { transmitted to joints or terminal screws. }\end{array}$ & $\square$ & $\square$ & $\square$ & \\
\hline $\begin{array}{l}\text { Cord, cable, and raceway connections are } \\
\text { intact and secure. }\end{array}$ & $\square$ & $\square$ & $\square$ & \\
\hline $\begin{array}{l}\text { Energized parts of electrical circuits and } \\
\text { equipment are guarded against accidental } \\
\text { contact by approved cabinets or enclosures. }\end{array}$ & $\square$ & $\square$ & $\square$ & \\
\hline $\begin{array}{l}\text { Unused openings (including conduit knockouts) } \\
\text { in electrical enclosures and fittings are closed } \\
\text { with appropriate covers, plugs, or plates. }\end{array}$ & $\square$ & $\square$ & $\square$ & \\
\hline
\end{tabular}




\begin{tabular}{|c|c|c|c|c|}
\hline Electrical Safety & Yes & No & N/A & Comments \\
\hline $\begin{array}{l}\text { Electrical enclosures such as switches, } \\
\text { receptacles, junction boxes, etc., are provided } \\
\text { with tight-fitting covers or plates. }\end{array}$ & $\square$ & $\square$ & $\square$ & \\
\hline $\begin{array}{l}\text { The location of electrical power lines and } \\
\text { cables (overhead, underground, under floor, } \\
\text { other side of walls, etc.) is determined before } \\
\text { digging, drilling, or similar work is begun. }\end{array}$ & $\square$ & $\square$ & $\square$ & \\
\hline $\begin{array}{l}\text { Temporary circuits are protected by suitable } \\
\text { disconnecting switches or plug connectors at } \\
\text { the junction with permanent wiring. }\end{array}$ & $\square$ & $\square$ & $\square$ & \\
\hline $\begin{array}{l}\text { Disconnecting switches for electrical motors } \\
\text { in excess of two horsepower are able to } \\
\text { open the circuit when the motor is stalled } \\
\text { without exploding. }\end{array}$ & $\square$ & $\square$ & $\square$ & \\
\hline $\begin{array}{l}\text { Low voltage protection is provided in the } \\
\text { control devices of motors driving machines } \\
\text { or equipment that could cause injury from } \\
\text { inadvertent starting. }\end{array}$ & $\square$ & $\square$ & $\square$ & \\
\hline $\begin{array}{l}\text { Motor disconnecting switches or circuit } \\
\text { breakers are located within sight of the } \\
\text { motor control device. }\end{array}$ & $\square$ & $\square$ & $\square$ & \\
\hline $\begin{array}{l}\text { The controller for each motor that exceeds } \\
\text { two horsepower is rated equal to, or above, } \\
\text { the rating of the motor it serves. }\end{array}$ & $\square$ & $\square$ & $\square$ & \\
\hline
\end{tabular}

\section{Additional Resources}

- OSHA Regulations:

- 29 CFR 1910.303, General Electrical Requirements

- 29 CFR 1910.305, Wiring Methods, Components, and Equipment for General Use

- 29 CFR 1910.334, Use of Electrical Equipment

- OSHA: Electrical

- NIOSH: Electrical Safety 


\section{Exit Routes and Emergency Planning}

\begin{tabular}{|c|c|c|c|c|}
\hline Doors & Yes & No & $\mathbf{N} / \mathbf{A}$ & Comments \\
\hline $\begin{array}{l}\text { Doors that are required to serve as exits are } \\
\text { designed and constructed so that the path of } \\
\text { exit travel is obvious and direct. }\end{array}$ & $\square$ & $\square$ & $\square$ & \\
\hline $\begin{array}{l}\text { Exit doors and doors in the required path to } \\
\text { the exit are not locked, blocked, or otherwise } \\
\text { obstructed. }\end{array}$ & $\square$ & $\square$ & $\square$ & \\
\hline $\begin{array}{l}\text { Exit doors can be opened from the direction } \\
\text { of exit travel without the use of a key, tool, } \\
\text { or any special knowledge or effort when the } \\
\text { building is occupied. }\end{array}$ & $\square$ & $\square$ & $\square$ & \\
\hline Exit doors are side-hinged and swing. & $\square$ & $\square$ & $\square$ & \\
\hline $\begin{array}{l}\text { No revolving, sliding, or overhead doors serve } \\
\text { as required exit doors. }\end{array}$ & $\square$ & $\square$ & $\square$ & \\
\hline $\begin{array}{l}\text { Panic hardware or fire exit hardware installed on } \\
\text { a required exit door allows the door to open by } \\
\text { applying a force of } 15 \text { pounds ( } 6.80 \text { kilograms) } \\
\text { or less in the direction of the exit traffic. }\end{array}$ & $\square$ & $\square$ & $\square$ & \\
\hline $\begin{array}{l}\text { Doors on cold storage rooms are provided } \\
\text { with an inside release mechanism that } \\
\text { releases the latch and open the door even if } \\
\text { the door is padlocked or otherwise locked on } \\
\text { the outside. }\end{array}$ & $\square$ & $\square$ & $\square$ & \\
\hline $\begin{array}{l}\text { Where exit doors open directly onto a street, } \\
\text { alley, or other area where vehicles may be } \\
\text { operated, adequate barriers and warnings are } \\
\text { provided to prevent workers from stepping } \\
\text { into the path of traffic. }\end{array}$ & $\square$ & $\square$ & $\square$ & \\
\hline
\end{tabular}




\begin{tabular}{|l|l|l|l|l|}
\hline Doors & Yes & No & N/A & Comments \\
\hline $\begin{array}{l}\text { Doors that swing in both directions and } \\
\text { are located between rooms where there is } \\
\text { frequent traffic are provided with viewing } \\
\text { panels in each door. }\end{array}$ & $\square$ & $\square$ & $\square$ & \\
\hline $\begin{array}{l}\text { Glass doors, glass panels in doors, windows, } \\
\text { etc., that are subject to human impact, } \\
\text { are made of safety glass that meets the } \\
\text { requirements for human impact. }\end{array}$ & $\square$ & $\square$ & $\square$ & \\
\hline
\end{tabular}

\section{Additional Resources}

- OSHA Regulations:

- 29 CFR 1910.35, Compliance with Alternative Exit-Route Codes

- 29 CFR 1910.36, Design and Construction Requirements for Exit Routes

- 29 CFR 1910.37, Maintenance, Safeguards, and Operational Features for Exit Routes

- OSHA: Design and Construction Requirements for Exit Routes 


\begin{tabular}{|c|c|c|c|c|}
\hline Emergency Action Plans & Yes & No & N/A & Comments \\
\hline $\begin{array}{l}\text { An emergency action plan is in place to } \\
\text { guide employer and worker actions during } \\
\text { workplace emergencies. } \\
\text { NOTE: While an emergency action plan } \\
\text { is only required when an OSHA standard } \\
\text { requires one, having a plan is a good way } \\
\text { to prepare and protect workers and the } \\
\text { business during an emergency. }\end{array}$ & $\square$ & $\square$ & $\square$ & \\
\hline $\begin{array}{l}\text { The plan considers all potential natural or } \\
\text { man-made emergencies that could disrupt } \\
\text { the workplace. }\end{array}$ & $\square$ & $\square$ & $\square$ & \\
\hline $\begin{array}{l}\text { The plan considers all potential internal } \\
\text { sources of emergencies that could disrupt } \\
\text { the workplace. }\end{array}$ & $\square$ & $\square$ & $\square$ & \\
\hline $\begin{array}{l}\text { The plan considers the impact of these } \\
\text { internal and external emergencies on } \\
\text { workplace operations and the response is } \\
\text { tailored to the workplace. }\end{array}$ & $\square$ & $\square$ & $\square$ & \\
\hline $\begin{array}{l}\text { The plan contains a list of key personnel } \\
\text { with contact information as well as contact } \\
\text { information for local emergency responders, } \\
\text { agencies, and contractors. }\end{array}$ & $\square$ & $\square$ & $\square$ & \\
\hline $\begin{array}{l}\text { The plan contains the names, titles, } \\
\text { departments, and telephone numbers } \\
\text { of individuals to contact for additional } \\
\text { information or an explanation of duties and } \\
\text { responsibilities under the plan. }\end{array}$ & $\square$ & $\square$ & $\square$ & \\
\hline $\begin{array}{l}\text { The plan addresses how medical assistance } \\
\text { will be provided. }\end{array}$ & $\square$ & $\square$ & $\square$ & \\
\hline
\end{tabular}




\begin{tabular}{|c|c|c|c|c|}
\hline Emergency Action Plans & Yes & No & N/A & Comments \\
\hline $\begin{array}{l}\text { The plan identifies how or where personal } \\
\text { information on workers can be obtained in } \\
\text { an emergency. }\end{array}$ & $\square$ & $\square$ & $\square$ & \\
\hline $\begin{array}{l}\text { The plan identifies the conditions under } \\
\text { which an evacuation would be necessary. }\end{array}$ & $\square$ & $\square$ & $\square$ & \\
\hline $\begin{array}{l}\text { The plan identifies a clear chain of command } \\
\text { and designates a person authorized to order } \\
\text { an evacuation or shutdown of operations. }\end{array}$ & $\square$ & $\square$ & $\square$ & \\
\hline $\begin{array}{l}\text { The plan addresses the types of actions } \\
\text { expected of different workers for the various } \\
\text { types of potential emergencies. }\end{array}$ & $\square$ & $\square$ & $\square$ & \\
\hline $\begin{array}{l}\text { The plan designates who, if anyone, will } \\
\text { stay to shut down critical operations during } \\
\text { an evacuation. }\end{array}$ & $\square$ & $\square$ & $\square$ & \\
\hline $\begin{array}{l}\text { The plan outlines specific evacuation routes } \\
\text { and exits and these are posted in the } \\
\text { workplace where they are easily accessible } \\
\text { to all workers. }\end{array}$ & $\square$ & $\square$ & $\square$ & \\
\hline $\begin{array}{l}\text { The plan address procedures for assisting } \\
\text { people during evacuations, particularly those } \\
\text { with disabilities or who do not speak English. }\end{array}$ & $\square$ & $\square$ & $\square$ & \\
\hline $\begin{array}{l}\text { The plan identifies one or more assembly } \\
\text { areas (as necessary for different types of } \\
\text { emergencies) where workers will gather and } \\
\text { a method for accounting for all workers. }\end{array}$ & $\square$ & $\square$ & $\square$ & \\
\hline $\begin{array}{l}\text { The plan addresses how visitors will be } \\
\text { assisted in evacuation and accounted for. }\end{array}$ & $\square$ & $\square$ & $\square$ & \\
\hline
\end{tabular}




\begin{tabular}{|l|c|c|c|c|}
\hline Emergency Action Plans & Yes & No & N/A & Comments \\
\hline $\begin{array}{l}\text { The plan identifies a preferred method for } \\
\text { reporting fires and other emergencies. }\end{array}$ & $\square$ & $\square$ & $\square$ & \\
\hline $\begin{array}{l}\text { The plan describes the method to be used to } \\
\text { alert workers, including disabled workers, to } \\
\text { evacuate or take other action. }\end{array}$ & $\square$ & $\square$ & $\square$ & \\
\hline
\end{tabular}

\section{Additional Resources}

- OSHA Regulations:

- 29 CFR 1910.38, Emergency Action Plans

- 29 CFR 1910.39, Fire Prevention Plans

- OSHA: Evacuation Plans and Procedures

- OSHA: Emergency Preparedness and Response

- OSHA: COVID-19

- CDC: COVID-19 


\begin{tabular}{|c|c|c|c|c|}
\hline Exits, Exit Paths (Means of Egress) & Yes & No & N/A & Comments \\
\hline $\begin{array}{l}\text { There are sufficient exits to permit prompt } \\
\text { escape in case of emergency. }\end{array}$ & $\square$ & $\square$ & $\square$ & \\
\hline $\begin{array}{l}\text { The number of exits from each floor or level, } \\
\text { and the number of exits from the building } \\
\text { itself, are appropriate for the occupant load. }\end{array}$ & $\square$ & $\square$ & $\square$ & \\
\hline $\begin{array}{l}\text { At least two means of egress are provided } \\
\text { from elevated platforms, pits, and rooms } \\
\text { where the absence of a second exit } \\
\text { would increase the risk of injury from hot, } \\
\text { poisonous, corrosive, suffocating, flammable, } \\
\text { or explosive substances. }\end{array}$ & $\square$ & $\square$ & $\square$ & \\
\hline $\begin{array}{l}\text { Routes (means of egress) to exits, when not } \\
\text { immediately apparent, are marked with } \\
\text { visible exit signs. }\end{array}$ & $\square$ & $\square$ & $\square$ & \\
\hline $\begin{array}{l}\text { All exits are marked with exit signs that are } \\
\text { illuminated either internally or by a reliable } \\
\text { light source. }\end{array}$ & $\square$ & $\square$ & $\square$ & \\
\hline $\begin{array}{l}\text { Exit signs are labeled with the word "EXIT" in } \\
\text { lettering at least } 6 \text { inches ( } 15.2 \text { centimeters) } \\
\text { high and the stroke of the lettering at least } \\
3 / 4 \text { inch ( } 1.9 \text { centimeters) wide. }\end{array}$ & $\square$ & $\square$ & $\square$ & \\
\hline $\begin{array}{l}\text { Doors, passageways and stairways that are } \\
\text { neither exits nor access to exits, but could } \\
\text { be mistaken for exits, are appropriately } \\
\text { marked "NOT AN EXIT," "TO BASEMENT," } \\
\text { "STOREROOM," etc. }\end{array}$ & $\square$ & $\square$ & $\square$ & \\
\hline $\begin{array}{l}\text { Emergency lighting, where provided, is } \\
\text { tested for } 30 \text { seconds each month, and } \\
\text { annually for } 90 \text { minutes. }\end{array}$ & $\square$ & $\square$ & $\square$ & \\
\hline
\end{tabular}




\begin{tabular}{|l|c|c|c|c|}
\hline Exits, Exit Paths (Means of Egress) & Yes & No & N/A & Comments \\
\hline $\begin{array}{l}\text { Ramps that are used as part of required } \\
\text { exiting from a building have a slope limited } \\
\text { to } 1 \text { foot (0.3048 meter) vertical and } 12 \text { feet } \\
\text { (3.6576 meters) horizontal. }\end{array}$ & $\square$ & $\square$ & $\square$ & \\
\hline
\end{tabular}

\section{Additional Resources}

- OSHA Regulations:

- 29 CFR 1910.35, Compliance with Alternative Exit-Route Codes

- 29 CFR 1910.36, Design and Construction Requirements for Exit Routes

- 29 CFR 1910.37, Maintenance, Safeguards, and Operational Features for Exit Routes

- 29 CFR 1910.38, Emergency Action Plans

- OSHA: Design and Construction Requirements for Exit Routes 


\section{Fire Protection}

\begin{tabular}{|c|c|c|c|c|}
\hline Fire Extinguishers & Yes & No & N/A & Comments \\
\hline $\begin{array}{l}\text { If portable fire extinguishers are provided } \\
\text { in the workplace, and designated workers } \\
\text { are expected to use them, the workers are } \\
\text { provided with initial training in their use and } \\
\text { at least annually thereafter. }\end{array}$ & $\square$ & $\square$ & $\square$ & \\
\hline $\begin{array}{l}\text { Portable fire extinguishers of the appropriate } \\
\text { types(s) are provided in adequate numbers, } \\
\text { and mounted in readily accessible locations. } \\
\text { NOTE: Refer to National Fire Protection } \\
\text { Association standard \#10 (NFPA 10) for } \\
\text { guidance on types, numbers, and locations. }\end{array}$ & $\square$ & $\square$ & $\square$ & \\
\hline $\begin{array}{l}\text { Fire extinguishers are selected and provided } \\
\text { for the types of materials in the areas where } \\
\text { they are to be used. } \\
\text { - Class A - Ordinary combustible materials. } \\
\text { - Class B - Flammable liquids, gases or oils. } \\
\text { - Class C - Energized-electrical equipment. } \\
\text { - Class D - Combustible metals. } \\
\text { - Class K - Kitchens; cooking with vegetable } \\
\text { or animal oils and fats. }\end{array}$ & $\square$ & $\square$ & $\square$ & \\
\hline $\begin{array}{l}\text { Fire extinguishers are visually inspected } \\
\text { monthly, and the inspection is recorded. }\end{array}$ & $\square$ & $\square$ & $\square$ & \\
\hline $\begin{array}{l}\text { Fire extinguisher discharge nozzles are free } \\
\text { from obstructions or blockage. }\end{array}$ & $\square$ & $\square$ & $\square$ & \\
\hline $\begin{array}{l}\text { Fire extinguishers are fully charged and in } \\
\text { their designated places. }\end{array}$ & $\square$ & $\square$ & $\square$ & \\
\hline $\begin{array}{l}\text { Fire extinguishers receive an annual } \\
\text { maintenance check, and the maintenance } \\
\text { is recorded. }\end{array}$ & $\square$ & $\square$ & $\square$ & \\
\hline
\end{tabular}

\section{Additional Resources}

- OSHA Regulations: 29 CFR 1910.157, Portable Fire Extinguishers

- OSHA: Portable Fire Extinguishers

- OSHA: Fire Safety 


\begin{tabular}{|c|c|c|c|c|}
\hline Fire Suppression and Alarm Systems & Yes & No & N/A & Comments \\
\hline $\begin{array}{l}\text { Fire alarm system has been certified, } \\
\text { is in proper working condition, and is } \\
\text { tested annually. }\end{array}$ & $\square$ & $\square$ & $\square$ & \\
\hline $\begin{array}{l}\text { Testing and maintenance of automatic } \\
\text { sprinkler systems is performed by a qualified } \\
\text { worker or sprinkler contractor. }\end{array}$ & $\square$ & $\square$ & $\square$ & \\
\hline $\begin{array}{l}\text { Automatic sprinkler system water control valves } \\
\text { and pressure gages are checked periodically. }\end{array}$ & $\square$ & $\square$ & $\square$ & \\
\hline $\begin{array}{l}\text { Sprinkler heads subject to potential physical } \\
\text { damage are protected by metal guards. }\end{array}$ & $\square$ & $\square$ & $\square$ & \\
\hline $\begin{array}{l}\text { Proper clearance (minimum } 18 \text { inches) is } \\
\text { maintained below sprinkler heads. }\end{array}$ & $\square$ & $\square$ & $\square$ & \\
\hline $\begin{array}{l}\text { Standpipes, fire hoses, and fire hose valves, } \\
\text { are inspected regularly and tested annually. }\end{array}$ & $\square$ & $\square$ & $\square$ & \\
\hline $\begin{array}{l}\text { Private fire hydrants are flushed at least } \\
\text { once a year and are on a routine preventive } \\
\text { maintenance schedule. }\end{array}$ & $\square$ & $\square$ & $\square$ & \\
\hline
\end{tabular}

\section{Additional Resources}

- OSHA Regulations:

- 29 CFR 1910.158, Standpipe and Hose Systems

- 29 CFR 1910.159, Automatic Sprinkler Systems

- 29 CFR 1910.160, Fixed Extinguishing Systems, General

- 29 CFR 1910.161, Fixed Extinguishing Systems, Dry Chemical

- 29 CFR 1910.162, Fixed Extinguishing Systems, Gaseous Agent

- 29 CFR 1910.163, Fixed Extinguishing Systems, Water Spray and Foam

- 29 CFR 1910.164, Fire Detection Systems

- 29 CFR 1910.165, Employee Alarm Systems

- OSHA: Fixed Extinguishing Systems

- OSHA: Fire Detection Systems

- OSHA: Employee Alarm Systems 


\begin{tabular}{|c|c|c|c|c|}
\hline $\begin{array}{l}\text { Flammable and Combustible Liquids } \\
\text { and Materials }\end{array}$ & Yes & No & N/A & Comments \\
\hline $\begin{array}{l}\text { Combustible scrap, debris and waste } \\
\text { materials (oily rags, etc.) are stored in covered } \\
\text { metal receptacles and promptly removed } \\
\text { from the worksite. }\end{array}$ & $\square$ & $\square$ & $\square$ & \\
\hline $\begin{array}{l}\text { Proper storage is practiced to minimize the risk } \\
\text { of fire, including spontaneous combustion. }\end{array}$ & $\square$ & $\square$ & $\square$ & \\
\hline $\begin{array}{l}\text { Approved containers and tanks are used } \\
\text { to store and handle flammable and } \\
\text { combustible liquids. }\end{array}$ & $\square$ & $\square$ & $\square$ & \\
\hline $\begin{array}{l}\text { All connections on drums and combustible } \\
\text { liquid piping are vapor and liquid tight. }\end{array}$ & $\square$ & $\square$ & $\square$ & \\
\hline $\begin{array}{l}\text { All flammable liquids are kept in closed } \\
\text { containers when not in use (e.g., parts } \\
\text { cleaning tanks, pans, etc.). }\end{array}$ & $\square$ & $\square$ & $\square$ & \\
\hline $\begin{array}{l}\text { Where flammable liquids are transferred } \\
\text { and dispensed, appropriate grounding and } \\
\text { bonding methods are used to minimize the } \\
\text { generation of static electricity. }\end{array}$ & $\square$ & $\square$ & $\square$ & \\
\hline $\begin{array}{l}\text { Inside storage rooms for flammable and } \\
\text { combustible liquids have mechanical or } \\
\text { gravity ventilation. }\end{array}$ & $\square$ & $\square$ & $\square$ & \\
\hline $\begin{array}{l}\text { Explosion-proof electrical wiring, lights, and } \\
\text { equipment are used, in inside storage rooms } \\
\text { used for flammable liquids. }\end{array}$ & $\square$ & $\square$ & $\square$ & \\
\hline $\begin{array}{l}\text { Liquefied petroleum gas is stored, handled, } \\
\text { and used in accordance with safe practices } \\
\text { and standards. }\end{array}$ & $\square$ & $\square$ & $\square$ & \\
\hline
\end{tabular}




\begin{tabular}{|c|c|c|c|c|}
\hline $\begin{array}{l}\text { Flammable and Combustible Liquids } \\
\text { and Materials }\end{array}$ & Yes & No & N/A & Comments \\
\hline $\begin{array}{l}\text { "NO SMOKING" signs are posted on liquefied } \\
\text { petroleum gas tanks. }\end{array}$ & $\square$ & $\square$ & $\square$ & \\
\hline $\begin{array}{l}\text { "NO SMOKING" signs are in areas where } \\
\text { flammable or combustible materials are used } \\
\text { and stored. }\end{array}$ & $\square$ & $\square$ & $\square$ & \\
\hline $\begin{array}{l}\text { Liquefied petroleum storage tanks are } \\
\text { guarded to prevent damage from vehicles. }\end{array}$ & $\square$ & $\square$ & $\square$ & \\
\hline $\begin{array}{l}\text { All solvent wastes and flammable liquids kept } \\
\text { in fire-resistant, covered containers until they } \\
\text { are removed from the worksite. }\end{array}$ & $\square$ & $\square$ & $\square$ & \\
\hline $\begin{array}{l}\text { Safety cans are used for dispensing } \\
\text { flammable or combustible liquids at the } \\
\text { point of use. }\end{array}$ & $\square$ & $\square$ & $\square$ & \\
\hline $\begin{array}{l}\text { Spills of flammable or combustible liquids are } \\
\text { cleaned up promptly. }\end{array}$ & $\square$ & $\square$ & $\square$ & \\
\hline $\begin{array}{l}\text { Storage tanks are adequately vented to } \\
\text { prevent the development of excessive vacuum } \\
\text { or pressure as a result of filling, emptying, or } \\
\text { atmosphere temperature changes. }\end{array}$ & $\square$ & $\square$ & $\square$ & \\
\hline $\begin{array}{l}\text { Storage tanks are equipped with emergency } \\
\text { venting that relieve excessive internal } \\
\text { pressure caused by fire exposure. }\end{array}$ & $\square$ & $\square$ & $\square$ & \\
\hline
\end{tabular}

\section{Additional Resources}

- OSHA Regulations

- 29 CFR 1910.106, Flammable Liquids

- 29 CFR 1910.107, Spray Finishing with Flammable and Combustible Materials 


\section{Hand and Portable Powered Tools and Equipment}

\begin{tabular}{|c|c|c|c|c|}
\hline $\begin{array}{l}\text { Explosive (Powder) Actuated } \\
\text { Fastening Tools }\end{array}$ & Yes & No & N/A & Comments \\
\hline $\begin{array}{l}\text { Each worker who operates an explosive- } \\
\text { actuated tool is trained in its use and has a } \\
\text { valid operator's card. }\end{array}$ & $\square$ & $\square$ & $\square$ & \\
\hline $\begin{array}{l}\text { Explosive-actuated tools are left unloaded } \\
\text { until they are ready to be used. }\end{array}$ & $\square$ & $\square$ & $\square$ & \\
\hline $\begin{array}{l}\text { Explosive-actuated tools are inspected for } \\
\text { obstructions or defects before use. }\end{array}$ & $\square$ & $\square$ & $\square$ & \\
\hline $\begin{array}{l}\text { Each explosive-actuated tool is stored in its } \\
\text { own locked container when not being used. }\end{array}$ & $\square$ & $\square$ & $\square$ & \\
\hline $\begin{array}{l}\text { Workers who operate explosive-actuated } \\
\text { tools use appropriate PPE. }\end{array}$ & $\square$ & $\square$ & $\square$ & \\
\hline $\begin{array}{l}\text { A sign at least } 7 \text { inches ( } 17.78 \text { centimeters) } \\
\text { by } 10 \text { inches ( } 25.40 \text { centimeters) with bold } \\
\text { face type reading "POWDER-" or "EXPLOSIVE- } \\
\text { ACTUATED TOOL IN USE" is conspicuously } \\
\text { posted when the tool is being used. }\end{array}$ & $\square$ & $\square$ & $\square$ & \\
\hline
\end{tabular}

\section{Additional Resources}

- OSHA Regulations: 29 CFR 1910.243, Guarding of Portable Powered Tools

- OSHA: Hand and Power Tools 


\begin{tabular}{|c|c|c|c|c|}
\hline Hand Tools and Equipment & Yes & No & N/A & Comments \\
\hline $\begin{array}{l}\text { Appropriate safety glasses, face shields, and } \\
\text { other PPE are used while using hand tools } \\
\text { or equipment that might produce flying } \\
\text { materials or be subject to breakage. }\end{array}$ & $\square$ & $\square$ & $\square$ & \\
\hline $\begin{array}{l}\text { All tools and equipment (both company and } \\
\text { worker-owned) used at the workplace are in } \\
\text { good condition. }\end{array}$ & $\square$ & $\square$ & $\square$ & \\
\hline $\begin{array}{l}\text { Workers have been advised of hazards } \\
\text { caused by faulty or improperly used } \\
\text { hand tools. }\end{array}$ & $\square$ & $\square$ & $\square$ & \\
\hline $\begin{array}{l}\text { Hand tools, such as chisels, punches, } \\
\text { etc., which develop mushroomed heads } \\
\text { during use are reconditioned or replaced } \\
\text { as necessary. }\end{array}$ & $\square$ & $\square$ & $\square$ & \\
\hline $\begin{array}{l}\text { Tools cutting edges are kept sharp so } \\
\text { that tools move smoothly without binding } \\
\text { or skipping. }\end{array}$ & $\square$ & $\square$ & $\square$ & \\
\hline $\begin{array}{l}\text { Tool handles are wedged tightly into the } \\
\text { heads of all tools. }\end{array}$ & $\square$ & $\square$ & $\square$ & \\
\hline $\begin{array}{l}\text { Broken or fractured handles on hammers, } \\
\text { axes, and similar equipment are replaced. }\end{array}$ & $\square$ & $\square$ & $\square$ & \\
\hline $\begin{array}{l}\text { Tools are stored in a dry, secure location } \\
\text { where tampering is not possible. }\end{array}$ & $\square$ & $\square$ & $\square$ & \\
\hline Worn or bent wrenches are replaced. & $\square$ & $\square$ & $\square$ & \\
\hline $\begin{array}{l}\text { Appropriate handles are used on files and } \\
\text { similar tools. }\end{array}$ & $\square$ & $\square$ & $\square$ & \\
\hline $\begin{array}{l}\text { Jacks are inspected to ensure they are in } \\
\text { good operating condition. }\end{array}$ & $\square$ & $\square$ & $\square$ & \\
\hline
\end{tabular}




\begin{tabular}{|l|c|c|c|c|}
\hline Hand Tools and Equipment & Yes & No & N/A & Comments \\
\hline $\begin{array}{l}\text { Jacks receive appropriate maintenance and } \\
\text { are lubricated at regular intervals. }\end{array}$ & $\square$ & $\square$ & $\square$ & \\
\hline Jacks only lift loads within their rated capacity. & $\square$ & $\square$ & $\square$ & \\
\hline
\end{tabular}

\section{Additional Resources}

- OSHA Regulations:

- 29 CFR 1910.242, Hand and Portable Powered Tools and Equipment

- 29 CFR 1910.243, Guarding of Portable Powered Tools

- 29 CFR 1910.244, Other Portable Tools and Equipment

- OSHA: Hand and Power Tools 


\begin{tabular}{|c|c|c|c|c|}
\hline $\begin{array}{l}\text { Portable (Power Operated) Tools } \\
\text { and Equipment }\end{array}$ & Yes & No & $\mathbf{N} / \mathbf{A}$ & Comments \\
\hline $\begin{array}{l}\text { Power tools are equipped with proper } \\
\text { shields, guards, or attachments, as } \\
\text { recommended by the manufacturer. }\end{array}$ & $\square$ & $\square$ & $\square$ & \\
\hline $\begin{array}{l}\text { Grinders, saws and other equipment are } \\
\text { provided with appropriate guards. }\end{array}$ & $\square$ & $\square$ & $\square$ & \\
\hline $\begin{array}{l}\text { Portable fans are provided with full guards } \\
\text { or screens having openings } 1 / 2 \text { inch } \\
\text { (1.2700 centimeters) or less. }\end{array}$ & $\square$ & $\square$ & $\square$ & \\
\hline $\begin{array}{l}\text { Portable circular saws are equipped with the } \\
\text { proper guards above and below the base } \\
\text { plate or shoe. }\end{array}$ & $\square$ & $\square$ & $\square$ & \\
\hline $\begin{array}{l}\text { Circular saw guards are checked to ensure } \\
\text { that they are not wedged up, leaving the } \\
\text { lower portion of the blade unguarded. }\end{array}$ & $\square$ & $\square$ & $\square$ & \\
\hline $\begin{array}{l}\text { Cord-connected, electrically operated tools } \\
\text { and equipment are effectively grounded or } \\
\text { of the approved double insulated type. }\end{array}$ & $\square$ & $\square$ & $\square$ & \\
\hline $\begin{array}{l}\text { Rotating or moving parts of equipment are } \\
\text { guarded to prevent physical contact. }\end{array}$ & $\square$ & $\square$ & $\square$ & \\
\hline $\begin{array}{l}\text { Pneumatic and hydraulic hoses on powder- } \\
\text { operated tools are checked regularly for } \\
\text { deterioration or damage. }\end{array}$ & $\square$ & $\square$ & $\square$ & \\
\hline
\end{tabular}

\section{Additional Resources}

- OSHA Regulations:

- 29 CFR 1910.242, Hand and Portable Powered Tools and Equipment

- 29 CFR 1910.243, Guarding of Portable Powered Tools

- 29 CFR 1910.244, Other Portable Tools and Equipment

- OSHA: Hand and Power Tools

- NIOSH: Nail Gun Safety

- NIOSH: Robotics

- NIOSH: Noise and Hearing Loss Prevention 


\section{Hazard Communication and Chemicals}

\begin{tabular}{|c|c|c|c|c|}
\hline Hazard Communication & Yes & No & N/A & Comments \\
\hline $\begin{array}{l}\text { A written plan has been developed to ensure } \\
\text { that workers are informed and understand } \\
\text { the hazards of chemicals in the workplace. }\end{array}$ & $\square$ & $\square$ & $\square$ & \\
\hline $\begin{array}{l}\text { A list or inventory of all hazardous chemicals } \\
\text { in the workplace has been prepared (including } \\
\text { housekeeping/cleaning chemicals). }\end{array}$ & $\square$ & $\square$ & $\square$ & \\
\hline $\begin{array}{l}\text { Safety Data Sheets (SDS) for each hazardous } \\
\text { chemical in the workplace are up-to-date } \\
\text { and readily accessible to workers. }\end{array}$ & $\square$ & $\square$ & $\square$ & \\
\hline $\begin{array}{l}\text { Labels are kept on shipped containers; } \\
\text { including: product identifier, signal } \\
\text { word, hazard statement(s), pictogram(s), } \\
\text { precautionary statement(s), and supplier } \\
\text { information. }\end{array}$ & $\square$ & $\square$ & $\square$ & \\
\hline $\begin{array}{l}\text { Workplace containers are labeled where } \\
\text { required (e.g., chemicals received in large } \\
\text { containers that are transferred to smaller } \\
\text { containers). }\end{array}$ & $\square$ & $\square$ & $\square$ & \\
\hline $\begin{array}{l}\text { Workplace signs and other forms of } \\
\text { communication are reviewed, revised, and } \\
\text { updated as appropriate, such as when new } \\
\text { information becomes available. }\end{array}$ & $\square$ & $\square$ & $\square$ & \\
\hline $\begin{array}{l}\text { Workers are trained on the requirements } \\
\text { of the hazard communication standard, } \\
\text { hazards of chemicals, appropriate protective } \\
\text { measures, and where and how to obtain } \\
\text { additional information. }\end{array}$ & $\square$ & $\square$ & $\square$ & \\
\hline $\begin{array}{l}\text { Workers are trained on the hazardous } \\
\text { chemicals in their work area before } \\
\text { initial assignment, and when new hazards } \\
\text { are introduced. }\end{array}$ & $\square$ & $\square$ & $\square$ & \\
\hline
\end{tabular}




\begin{tabular}{|l|l|l|l|l|}
\hline Hazard Communication & Yes & No & N/A & Comments \\
\hline $\begin{array}{l}\text { Workers understand SDS and where to } \\
\text { find them. }\end{array}$ & $\square$ & $\square$ & $\square$ & \\
\hline $\begin{array}{l}\text { Workers understand labels received on } \\
\text { shipped containers and details of the } \\
\text { workplace labeling system. }\end{array}$ & $\square$ & $\square$ & $\square$ & \\
\hline $\begin{array}{l}\text { The hazard communication program } \\
\text { is reviewed periodically to ensure it is } \\
\text { meeting its objectives, and is revised/ } \\
\text { updated as appropriate to address changes } \\
\text { in the workplace (e.g., new chemicals, new } \\
\text { hazards, etc.). }\end{array}$ & $\square$ & $\square$ & $\square$ & \\
\hline
\end{tabular}

\section{Additional Resources}

- OSHA Regulations: 29 CFR 1910.1200, Hazard Communication

- OSHA: Hazard Communication

- OSHA: Hazard Communication - Small Entity Compliance Guide 


\begin{tabular}{|c|c|c|c|c|}
\hline Hazardous Chemicals & Yes & No & N/A & Comments \\
\hline $\begin{array}{l}\text { A written hazardous communication } \\
\text { program is in place for the workplace. }\end{array}$ & $\square$ & $\square$ & $\square$ & \\
\hline $\begin{array}{l}\text { Workers have been informed about all } \\
\text { operations where hazardous chemicals } \\
\text { are present. }\end{array}$ & $\square$ & $\square$ & $\square$ & \\
\hline $\begin{array}{l}\text { Containers of hazardous chemicals are } \\
\text { labeled and Safety Data Sheets are available } \\
\text { (see Hazard Communication section above). }\end{array}$ & $\square$ & $\square$ & $\square$ & \\
\hline $\begin{array}{l}\text { Eye-wash fountains and safety showers are } \\
\text { provided and maintained in areas where } \\
\text { hazardous chemicals are handled. }\end{array}$ & $\square$ & $\square$ & $\square$ & \\
\hline $\begin{array}{l}\text { Chemical piping systems are clearly marked } \\
\text { as to their contents. }\end{array}$ & $\square$ & $\square$ & $\square$ & \\
\hline $\begin{array}{l}\text { Worker exposure to hazardous chemicals is } \\
\text { kept within acceptable levels. }\end{array}$ & $\square$ & $\square$ & $\square$ & \\
\hline $\begin{array}{l}\text { Medical or biological monitoring systems } \\
\text { are in operation for eligible workers (e.g., } \\
\text { exposure to cadmium, lead). }\end{array}$ & $\square$ & $\square$ & $\square$ & \\
\hline $\begin{array}{l}\text { Workers use appropriate personal protective } \\
\text { clothing and equipment when handling } \\
\text { hazardous chemicals (e.g., gloves, eye/face } \\
\text { protection, respirators, etc.). }\end{array}$ & $\square$ & $\square$ & $\square$ & \\
\hline $\begin{array}{l}\text { Chemicals are kept in closed containers when } \\
\text { not in use. }\end{array}$ & $\square$ & $\square$ & $\square$ & \\
\hline $\begin{array}{l}\text { Materials that give off toxic, asphyxiant, } \\
\text { suffocating, or anesthetic fumes are stored in } \\
\text { remote or isolated locations when not in use. }\end{array}$ & $\square$ & $\square$ & $\square$ & \\
\hline
\end{tabular}




\begin{tabular}{|l|l|l|l|l|}
\hline Hazardous Chemicals & Yes & No & N/A & Comments \\
\hline $\begin{array}{l}\text { Standard operating procedures for cleaning } \\
\text { up chemical spills are established and are } \\
\text { being followed. }\end{array}$ & $\square$ & $\square$ & $\square$ & \\
\hline $\begin{array}{l}\text { Corrosive liquids that are frequently handled } \\
\text { in open containers, or drawn from storage } \\
\text { vessels or pipelines, have adequate means } \\
\text { readily available for neutralizing or disposing } \\
\text { of spills or overflows, and clean-up is } \\
\text { performed properly and safely. }\end{array}$ & $\square$ & $\square$ & $\square$ & \\
\hline $\begin{array}{l}\text { Hazardous substances are handled in } \\
\text { properly designed and exhausted booths or } \\
\text { similar locations, where possible. }\end{array}$ & $\square$ & $\square$ & $\square$ & \\
\hline
\end{tabular}

\section{Additional Resources}

- OSHA Regulations:

- 29 CFR 1910.1200, Hazard Communication

- 29 CFR 1910 Subpart Z, Toxic and Hazardous Substances

- OSHA: Chemical Hazards and Toxic Substances

- OSHA: Occupational Chemical Database

- OSHA: Transitioning to Safer Chemicals

- NIOSH: Managing Chemical Safety in the Workplace

- NIOSH: Pocket Guide to Chemical Hazards

- NIOSH: Nanotechnology 


\section{Lockout/Tagout Procedures}

\begin{tabular}{|c|c|c|c|c|}
\hline Lockout/Tagout Procedures & Yes & No & $\mathbf{N} / \mathbf{A}$ & Comments \\
\hline $\begin{array}{l}\text { A lockout/tagout procedure has been } \\
\text { developed in writing, and is reviewed at } \\
\text { least annually. }\end{array}$ & $\square$ & $\square$ & $\square$ & \\
\hline $\begin{array}{l}\text { The lockout procedure requires that stored } \\
\text { energy (mechanical, hydraulic, air, etc.) is } \\
\text { released or blocked before equipment is } \\
\text { locked out for service and maintenance. }\end{array}$ & $\square$ & $\square$ & $\square$ & \\
\hline $\begin{array}{l}\text { Authorized workers have been trained on the } \\
\text { lockout/tagout procedure, and are provided } \\
\text { with personal safety locks or other approved } \\
\text { lockout devices. }\end{array}$ & $\square$ & $\square$ & $\square$ & \\
\hline $\begin{array}{l}\text { A means is provided to identify the worker(s) } \\
\text { working on locked out equipment by the } \\
\text { lock(s) or accompanying tag(s). }\end{array}$ & $\square$ & $\square$ & $\square$ & \\
\hline $\begin{array}{l}\text { Machinery or equipment is locked out } \\
\text { at the main power source; not at a push } \\
\text { button, selector switch, or other control } \\
\text { circuit type device. }\end{array}$ & $\square$ & $\square$ & $\square$ & \\
\hline $\begin{array}{l}\text { Equipment control valve handles are } \\
\text { provided with a means for locking out. }\end{array}$ & $\square$ & $\square$ & $\square$ & \\
\hline $\begin{array}{l}\text { For equipment or lines that cannot be shut } \\
\text { down, or locked out and tagged, a safe job } \\
\text { procedure is established and rigidly followed. }\end{array}$ & $\square$ & $\square$ & $\square$ & \\
\hline $\begin{array}{l}\text { Energy source isolation is verified before } \\
\text { work begins. }\end{array}$ & $\square$ & $\square$ & $\square$ & \\
\hline $\begin{array}{l}\text { Verification is accomplished by testing } \\
\text { machinery, gauges, or other approved means. }\end{array}$ & $\square$ & $\square$ & $\square$ & \\
\hline
\end{tabular}




\begin{tabular}{|c|c|c|c|c|}
\hline Lockout/Tagout Procedures & Yes & No & N/A & Comments \\
\hline $\begin{array}{l}\text { Machinery and equipment capable of } \\
\text { movement is de-energized, or disengaged } \\
\text { and blocked, or locked out during cleaning, } \\
\text { servicing, adjusting, or setting up operations. }\end{array}$ & $\square$ & $\square$ & $\square$ & \\
\hline $\begin{array}{l}\text { Where the disconnecting means for } \\
\text { equipment does not also disconnect the } \\
\text { electrical control circuit, the appropriate } \\
\text { electrical enclosures are identified; and a } \\
\text { means is provided to assure the control circuit } \\
\text { can also be disconnected and locked out. }\end{array}$ & $\square$ & $\square$ & $\square$ & \\
\hline $\begin{array}{l}\text { Workers keep personal control of their keys } \\
\text { while they have safety locks in use. }\end{array}$ & $\square$ & $\square$ & $\square$ & \\
\hline $\begin{array}{l}\text { Only the worker exposed to the hazard is } \\
\text { permitted to place or remove the safety lock. }\end{array}$ & $\square$ & $\square$ & $\square$ & \\
\hline $\begin{array}{l}\text { Workers check the safety of the lockout by } \\
\text { attempting a startup after making sure no } \\
\text { one is exposed. }\end{array}$ & $\square$ & $\square$ & $\square$ & \\
\hline $\begin{array}{l}\text { A sufficient number of accident prevention } \\
\text { signs or tags and safety padlocks are } \\
\text { provided for any reasonably foreseeable } \\
\text { repair emergency. }\end{array}$ & $\square$ & $\square$ & $\square$ & \\
\hline $\begin{array}{l}\text { When machine operations, configuration, } \\
\text { or size make it necessary for the operator } \\
\text { to leave the control station, and part of the } \\
\text { machine could move if accidentally activated, } \\
\text { the part is separately locked out or blocked. }\end{array}$ & $\square$ & $\square$ & $\square$ & \\
\hline
\end{tabular}

\section{Additional Resources}

- OSHA Regulations: 29 CFR 1910.147, Control of Hazardous Energy (Lockout/Tagout)

- OSHA: Control of Hazardous Energy (Lockout/Tagout)

- OSHA: Lockout-Tagout Interactive Training Program

- NIOSH: Using Lockout and Tagout Procedures to Prevent Injury and Death during Machine Maintenance 


\section{Machinery and Machine Guarding}

\begin{tabular}{|c|c|c|c|c|}
\hline Abrasive Wheel Equipment Grinders & Yes & No & N/A & Comments \\
\hline $\begin{array}{l}\text { Bench and pedestal grinders are } \\
\text { permanently mounted. }\end{array}$ & $\square$ & $\square$ & $\square$ & \\
\hline $\begin{array}{l}\text { Abrasive grinders have safety guards that } \\
\text { cover the spindle, nut and flange projections; } \\
\text { the guards are mounted to maintain } \\
\text { proper alignment with the wheel; and } \\
\text { the strength of the fastenings exceed the } \\
\text { strength of the guards. }\end{array}$ & $\square$ & $\square$ & $\square$ & \\
\hline $\begin{array}{l}\text { Work rests are used and kept adjusted to within } \\
1 / 8 \text { inch ( } 0.3175 \text { centimeter) of the wheel. }\end{array}$ & $\square$ & $\square$ & $\square$ & \\
\hline $\begin{array}{l}\text { The adjustable tongue on the top side of the } \\
\text { grinder is used and kept adjusted to within } \\
1 / 4 \text { inch ( } 0.6350 \text { centimeters) of the wheel. }\end{array}$ & $\square$ & $\square$ & $\square$ & \\
\hline $\begin{array}{l}\text { Vertical or Right Angle Head portable grinder } \\
\text { safety guards are located between the } \\
\text { operator and wheel during use, and have a } \\
\text { maximum exposure angle of } 180 \text { degrees. }\end{array}$ & $\square$ & $\square$ & $\square$ & \\
\hline $\begin{array}{l}\text { The maximum revolutions per minute (rpm) } \\
\text { rating of each abrasive wheel is compatible } \\
\text { with the rpm rating of the grinder motor. }\end{array}$ & $\square$ & $\square$ & $\square$ & \\
\hline $\begin{array}{l}\text { Each grinder has an individual on and off } \\
\text { control switch. }\end{array}$ & $\square$ & $\square$ & $\square$ & \\
\hline $\begin{array}{l}\text { All hand-held grinders shall have the } \\
\text { appropriate power control switch } \\
\text { configuration. }\end{array}$ & $\square$ & $\square$ & $\square$ & \\
\hline $\begin{array}{l}\text { New abrasive wheels are visually inspected } \\
\text { and ring tested before they are mounted. }\end{array}$ & $\square$ & $\square$ & $\square$ & \\
\hline
\end{tabular}




\begin{tabular}{|c|c|c|c|c|}
\hline Abrasive Wheel Equipment Grinders & Yes & No & N/A & Comments \\
\hline $\begin{array}{l}\text { Dust collectors and powered exhausts are } \\
\text { provided on grinders used in operations that } \\
\text { produce large amounts of dust. }\end{array}$ & $\square$ & $\square$ & $\square$ & \\
\hline $\begin{array}{l}\text { Splash guards are mounted on grinders that } \\
\text { use coolant to prevent the coolant from } \\
\text { reaching workers. }\end{array}$ & $\square$ & $\square$ & $\square$ & \\
\hline Workers use appropriate PPE when grinding. & $\square$ & $\square$ & $\square$ & \\
\hline
\end{tabular}

\section{Additional Resources}

- OSHA Regulations: 29 CFR 1910.215, Abrasive Wheel Machinery

- OSHA: Abrasive Wheel Grinder Checklist

- NIOSH: Abrasive Blasting 


\begin{tabular}{|c|c|c|c|c|}
\hline Machinery and Equipment & Yes & No & N/A & Comments \\
\hline $\begin{array}{l}\text { Fixed machines are anchored to prevent } \\
\text { tipping or other movement. }\end{array}$ & $\square$ & $\square$ & $\square$ & \\
\hline $\begin{array}{l}\text { The operator and other workers in the } \\
\text { machine area are protected from hazards } \\
\text { created at the point of operation, ingoing nip } \\
\text { points, rotating parts, flying chips, and sparks. }\end{array}$ & $\square$ & $\square$ & $\square$ & \\
\hline $\begin{array}{l}\text { Operators use special hand tools for placing } \\
\text { and removing material where needed to } \\
\text { protect their hands. }\end{array}$ & $\square$ & $\square$ & $\square$ & \\
\hline $\begin{array}{l}\text { Machine guards are secured and arranged so } \\
\text { they do not cause a hazard while in use. }\end{array}$ & $\square$ & $\square$ & $\square$ & \\
\hline $\begin{array}{l}\text { Revolving drums, barrels, and containers are } \\
\text { guarded by an enclosure that is interlocked } \\
\text { with the drive mechanism so that revolution } \\
\text { cannot occur unless the guard enclosure is } \\
\text { in place. }\end{array}$ & $\square$ & $\square$ & $\square$ & \\
\hline $\begin{array}{l}\text { Fan blades are protected with a guard } \\
\text { having openings no larger than I/ } 2 \text { inch } \\
\text { ( } 1.2700 \text { centimeters) when operating } \\
\text { within } 7 \text { feet ( } 2.1336 \text { meters) of the floor } \\
\text { or working level. }\end{array}$ & $\square$ & $\square$ & $\square$ & \\
\hline $\begin{array}{l}\text { Pulleys and belts within } 7 \text { feet ( } 2.1336 \text { meters) of } \\
\text { the floor or working level are properly guarded. }\end{array}$ & $\square$ & $\square$ & $\square$ & \\
\hline Moving chains and gears are properly guarded. & $\square$ & $\square$ & $\square$ & \\
\hline $\begin{array}{l}\text { Workers are trained on safe methods of } \\
\text { machine operation. }\end{array}$ & $\square$ & $\square$ & $\square$ & \\
\hline $\begin{array}{l}\text { A program is in place for regular safety } \\
\text { inspections of machinery and equipment. }\end{array}$ & $\square$ & $\square$ & $\square$ & \\
\hline $\begin{array}{l}\text { All machinery and equipment are kept clean } \\
\text { and properly maintained. }\end{array}$ & $\square$ & $\square$ & $\square$ & \\
\hline
\end{tabular}




\begin{tabular}{|c|c|c|c|c|}
\hline Machinery and Equipment & Yes & No & N/A & Comments \\
\hline $\begin{array}{l}\text { Sufficient clearance is provided around } \\
\text { and between machines to allow for safe } \\
\text { operations, set up and servicing, material } \\
\text { handling and waste removal. }\end{array}$ & $\square$ & $\square$ & $\square$ & \\
\hline $\begin{array}{l}\text { A power shut-off switch is provided } \\
\text { within reach of the operator's position } \\
\text { at each machine. }\end{array}$ & $\square$ & $\square$ & $\square$ & \\
\hline $\begin{array}{l}\text { Hazardous energy to machines and } \\
\text { equipment can be locked out for servicing } \\
\text { and maintenance. }\end{array}$ & $\square$ & $\square$ & $\square$ & \\
\hline $\begin{array}{l}\text { Noncurrent-carrying metal parts of } \\
\text { electrically operated machines are bonded } \\
\text { and grounded. }\end{array}$ & $\square$ & $\square$ & $\square$ & \\
\hline $\begin{array}{l}\text { Foot-operated switches are guarded or } \\
\text { arranged to prevent accidental actuation by } \\
\text { a person or falling object. }\end{array}$ & $\square$ & $\square$ & $\square$ & \\
\hline $\begin{array}{l}\text { Manually operated valves and switches } \\
\text { controlling the operation of equipment } \\
\text { and machines clearly identified and } \\
\text { readily accessible. }\end{array}$ & $\square$ & $\square$ & $\square$ & \\
\hline Emergency stop buttons are colored red. & $\square$ & $\square$ & $\square$ & \\
\hline $\begin{array}{l}\text { Splash guards are mounted on machines } \\
\text { that use coolant to prevent the coolant from } \\
\text { reaching workers. }\end{array}$ & $\square$ & $\square$ & $\square$ & \\
\hline $\begin{array}{l}\text { Arbors and mandrels have firm and secure } \\
\text { bearings, and are free of play. }\end{array}$ & $\square$ & $\square$ & $\square$ & \\
\hline $\begin{array}{l}\text { Provisions are made to prevent machines } \\
\text { from automatically starting when power is } \\
\text { restored after a power failure or shutdown. }\end{array}$ & $\square$ & $\square$ & $\square$ & \\
\hline
\end{tabular}




\begin{tabular}{|l|l|l|l|l|}
\hline Machinery and Equipment & Yes & No & N/A & Comments \\
\hline $\begin{array}{l}\text { Machines are constructed so as to be free } \\
\text { from excessive vibration when the largest } \\
\text { size tool is mounted and run at full speed. }\end{array}$ & $\square$ & $\square$ & $\square$ & \\
\hline $\begin{array}{l}\text { Saws used for ripping are equipped with } \\
\text { anti-kickback devices and spreaders. }\end{array}$ & $\square$ & $\square$ & $\square$ & \\
\hline $\begin{array}{l}\text { Radial arm saws are arranged so that the } \\
\text { cutting head gently returns to the back of the } \\
\text { table when released. }\end{array}$ & $\square$ & $\square$ & $\square$ & \\
\hline
\end{tabular}

\section{Additional Resources}

- OSHA Regulations: 29 CFR 1910.212, General Requirements for All Machines

- OSHA: Machine Guarding

- NIOSH: Machine Safety 


\section{Materials Handling and Storage}

\begin{tabular}{|c|c|c|c|c|}
\hline Hoist and Auxiliary Equipment & Yes & No & N/A & Comments \\
\hline $\begin{array}{l}\text { Hoisting equipment is available and used for } \\
\text { lifting heavy objects, and hoist ratings and } \\
\text { characteristics are appropriate for the task. }\end{array}$ & $\square$ & $\square$ & $\square$ & \\
\hline $\begin{array}{l}\text { Overhead and gantry cranes are periodically } \\
\text { inspected for defects or safety concerns } \\
\text { in } 1 \text { to } 12 \text { month intervals depending on } \\
\text { equipment activity, severity of service, } \\
\text { and environment. }\end{array}$ & $\square$ & $\square$ & $\square$ & \\
\hline $\begin{array}{l}\text { All ropes are thoroughly inspected at least } \\
\text { once a month and a certification record } \\
\text { which includes the inspection date, inspector } \\
\text { signature, and an identifier for inspected } \\
\text { ropes, is kept on file. }\end{array}$ & $\square$ & $\square$ & $\square$ & \\
\hline $\begin{array}{l}\text { All equipment with obvious signs of } \\
\text { deterioration, leakage, or deformation is } \\
\text { inspected daily. }\end{array}$ & $\square$ & $\square$ & $\square$ & \\
\hline $\begin{array}{l}\text { Hooks with deformation or cracks and hoist } \\
\text { chains, including end connections, are visually } \\
\text { inspected daily and have a monthly inspection } \\
\text { documented with a certification record. }\end{array}$ & $\square$ & $\square$ & $\square$ & \\
\hline $\begin{array}{l}\text { Each overhead electric hoist is equipped with } \\
\text { a limit switch/device to stop the hook at its } \\
\text { highest and lowest point of safe travel. }\end{array}$ & $\square$ & $\square$ & $\square$ & \\
\hline $\begin{array}{l}\text { Each hoist automatically stops and holds any } \\
\text { load up to } 125 \text { percent of its rated load if its } \\
\text { actuating force is removed. }\end{array}$ & $\square$ & $\square$ & $\square$ & \\
\hline $\begin{array}{l}\text { The rated load of each hoist is legibly marked } \\
\text { and visible to the operator. }\end{array}$ & $\square$ & $\square$ & $\square$ & \\
\hline $\begin{array}{l}\text { Stops are provided at the safe limits of travel } \\
\text { for trolley hoists. }\end{array}$ & $\square$ & $\square$ & $\square$ & \\
\hline
\end{tabular}




\begin{tabular}{|c|c|c|c|c|}
\hline Hoist and Auxiliary Equipment & Yes & No & N/A & Comments \\
\hline $\begin{array}{l}\text { Pendant control boxes are constructed to } \\
\text { prevent electrical shock and have clearly } \\
\text { labelled functions. }\end{array}$ & $\square$ & $\square$ & $\square$ & \\
\hline $\begin{array}{l}\text { Pendant control stations are kept clean and } \\
\text { function labels kept legible. }\end{array}$ & $\square$ & $\square$ & $\square$ & \\
\hline $\begin{array}{l}\text { Each cage-controlled hoist is equipped with } \\
\text { an effective warning device. }\end{array}$ & $\square$ & $\square$ & $\square$ & \\
\hline $\begin{array}{l}\text { Close-fitting guards or other suitable } \\
\text { devices are installed on each hoist to ensure } \\
\text { that hoist ropes will be maintained in the } \\
\text { sheave grooves. }\end{array}$ & $\square$ & $\square$ & $\square$ & \\
\hline $\begin{array}{l}\text { Hoist chains or ropes are long enough to } \\
\text { handle the full range of movement of the } \\
\text { application while maintaining two full wraps } \\
\text { around the drum at all times. }\end{array}$ & $\square$ & $\square$ & $\square$ & \\
\hline $\begin{array}{l}\text { Guards are provided for nip points or } \\
\text { contact points between hoist ropes and } \\
\text { sheaves permanently located within } 7 \text { feet } \\
\text { ( } 2.1336 \text { meters) of the floor, ground, or } \\
\text { working platform. }\end{array}$ & $\square$ & $\square$ & $\square$ & \\
\hline $\begin{array}{l}\text { Workers do not use twisted or kinked hoist } \\
\text { chains or hoist ropes. }\end{array}$ & $\square$ & $\square$ & $\square$ & \\
\hline $\begin{array}{l}\text { Workers do not use hoist ropes or hoist } \\
\text { chains wrapped around the load as a } \\
\text { substitute for a sling. }\end{array}$ & $\square$ & $\square$ & $\square$ & \\
\hline $\begin{array}{l}\text { The load is well secured and properly balanced } \\
\text { before it is lifted more than a few inches. }\end{array}$ & $\square$ & $\square$ & $\square$ & \\
\hline $\begin{array}{l}\text { Operators are instructed to avoid carrying } \\
\text { loads above people, and provisions are } \\
\text { made to ensure that no one is below hoisted } \\
\text { material or equipment. }\end{array}$ & $\square$ & $\square$ & $\square$ & \\
\hline
\end{tabular}




\begin{tabular}{|c|c|c|c|c|}
\hline Hoist and Auxiliary Equipment & Yes & No & N/A & Comments \\
\hline $\begin{array}{l}\text { All unsafe conditions, identified by } \\
\text { inspections, are corrected by designated } \\
\text { workers before crane operation resumes. }\end{array}$ & $\square$ & $\square$ & $\square$ & \\
\hline $\begin{array}{l}\text { Safety latches and other devices are } \\
\text { used to prevent slippage of materials } \\
\text { off hoisting hooks. }\end{array}$ & $\square$ & $\square$ & $\square$ & \\
\hline $\begin{array}{l}\text { Chains, ropes, chokers, and slings are } \\
\text { adequate for the materials they are securing. }\end{array}$ & $\square$ & $\square$ & $\square$ & \\
\hline $\begin{array}{l}\text { Hoist controls are plainly marked to indicate } \\
\text { the direction of travel or motion. }\end{array}$ & $\square$ & $\square$ & $\square$ & \\
\hline
\end{tabular}

\section{Additional Resources}

- OSHA Regulations:

- 29 CFR 1910.179, Overhead and Gantry Cranes

- 29 CFR 1910.181, Derricks

- 29 CFR 1910.184, Slings

- 29 CFR 1910.219, Mechanical Power-Transmission Apparatus

- OSHA: Crane, Derrick and Hoist Safety

- NIOSH Alert Preventing Worker Injuries and Deaths from Mobile Crane Tip-Over, Boom Collapse, and Uncontrolled Hoisted Loads 


\begin{tabular}{|c|c|c|c|c|}
\hline Materials Handling & Yes & No & N/A & Comments \\
\hline $\begin{array}{l}\text { There is safe clearance for materials handling } \\
\text { equipment through aisles and doorways. }\end{array}$ & $\square$ & $\square$ & $\square$ & \\
\hline $\begin{array}{l}\text { Aisles are permanently marked and kept clear } \\
\text { to allow unhindered passage. }\end{array}$ & $\square$ & $\square$ & $\square$ & \\
\hline $\begin{array}{l}\text { Hand trucks, pallet jacks, powered industrial } \\
\text { trucks, and other equipment used for } \\
\text { materials handling are maintained in safe } \\
\text { operating condition. }\end{array}$ & $\square$ & $\square$ & $\square$ & \\
\hline $\begin{array}{l}\text { Motorized hand and hand/rider trucks are } \\
\text { designed so that when the operator releases } \\
\text { the grip on the device that controls the } \\
\text { truck's travel, the brakes are applied and } \\
\text { power to the drive motor shuts off. }\end{array}$ & $\square$ & $\square$ & $\square$ & \\
\hline $\begin{array}{l}\text { Trucks and trailers are secured from movement } \\
\text { during loading and unloading operations. }\end{array}$ & $\square$ & $\square$ & $\square$ & \\
\hline $\begin{array}{l}\text { Dockboards (bridge plates) are used when } \\
\text { loading and unloading operations are taking } \\
\text { place between vehicles and docks. }\end{array}$ & $\square$ & $\square$ & $\square$ & \\
\hline $\begin{array}{l}\text { Dockboards are capable of supporting the } \\
\text { maximum intended load. }\end{array}$ & $\square$ & $\square$ & $\square$ & \\
\hline $\begin{array}{l}\text { Chutes and gravity roller sections are firmly } \\
\text { placed or secured to prevent displacement. }\end{array}$ & $\square$ & $\square$ & $\square$ & \\
\hline $\begin{array}{l}\text { Chutes are equipped with sideboards of } \\
\text { sufficient height to prevent the materials being } \\
\text { handled from falling off, and provisions are } \\
\text { made to brake the movement of the handled } \\
\text { materials at the delivery end of rollers or chutes. }\end{array}$ & $\square$ & $\square$ & $\square$ & \\
\hline $\begin{array}{l}\text { Pallets are inspected before being loaded } \\
\text { or moved. }\end{array}$ & $\square$ & $\square$ & $\square$ & \\
\hline
\end{tabular}

\section{Additional Resources}

- OSHA Regulations:

- 29 CFR 1910.176, Handling Materials

- 29 CFR 1910.178, Powered Industrial Trucks

- OSHA: Materials Handling and Storage 


\begin{tabular}{|c|c|c|c|c|}
\hline Powered Industrial Trucks & Yes & No & N/A & Comments \\
\hline $\begin{array}{l}\text { Workers are properly trained, and certified } \\
\text { by the employer, to use of the type(s) of } \\
\text { powered industrial truck(s) (PIT) they operate, } \\
\text { and only trained workers operate the PIT. }\end{array}$ & $\square$ & $\square$ & $\square$ & \\
\hline $\begin{array}{l}\text { Operator training and evaluation is } \\
\text { conducted by someone who has the } \\
\text { knowledge, training, and experience to train } \\
\text { PIT operators. }\end{array}$ & $\square$ & $\square$ & $\square$ & \\
\hline $\begin{array}{l}\text { PIT operator performance is evaluated at } \\
\text { least once every three years, and workers } \\
\text { are retrained as necessary. }\end{array}$ & $\square$ & $\square$ & $\square$ & \\
\hline $\begin{array}{l}\text { Overhead protection is provided on high-lift } \\
\text { rider trucks, unless it interferes with the } \\
\text { operating conditions. }\end{array}$ & $\square$ & $\square$ & $\square$ & \\
\hline $\begin{array}{l}\text { Any modifications and additions that } \\
\text { affect PIT capacity and safe operations are } \\
\text { only performed with manufacturer's prior } \\
\text { written approval. }\end{array}$ & $\square$ & $\square$ & $\square$ & \\
\hline $\begin{array}{l}\text { PITs equipped with non-factory installed } \\
\text { front-end attachments are marked to identify } \\
\text { the attachments and show the approximate } \\
\text { weight of the truck and attachments } \\
\text { combination at maximum elevation with the } \\
\text { load laterally centered. }\end{array}$ & $\square$ & $\square$ & $\square$ & \\
\hline $\begin{array}{l}\text { Warning labels, tags, decals, plates, markings, } \\
\text { etc., are updated, legible, and maintained. }\end{array}$ & $\square$ & $\square$ & $\square$ & \\
\hline $\begin{array}{l}\text { Directional lighting is provided on PITs that } \\
\text { operate in areas with inadequate general } \\
\text { lighting (less than 2-lumens per square foot). }\end{array}$ & $\square$ & $\square$ & $\square$ & \\
\hline $\begin{array}{l}\text { PITs are operated at speeds that allow them } \\
\text { to stop in a safe manner, under all travel } \\
\text { conditions and acceptable loading levels. }\end{array}$ & $\square$ & $\square$ & $\square$ & \\
\hline $\begin{array}{l}\text { Parking brakes prevent the PIT from moving } \\
\text { when unattended. }\end{array}$ & $\square$ & $\square$ & $\square$ & \\
\hline
\end{tabular}




\begin{tabular}{|c|c|c|c|c|}
\hline Powered Industrial Trucks & Yes & No & N/A & Comments \\
\hline $\begin{array}{l}\text { PITs that operate in hazardous environments } \\
\text { are approved for use in such locations. }\end{array}$ & $\square$ & $\square$ & $\square$ & \\
\hline $\begin{array}{l}\text { Safe distances are maintained from the edges } \\
\text { of elevated ramps and platforms. }\end{array}$ & $\square$ & $\square$ & $\square$ & \\
\hline $\begin{array}{l}\text { Workers do not stand or pass under elevated } \\
\text { portions of PITs, whether loaded or empty. }\end{array}$ & $\square$ & $\square$ & $\square$ & \\
\hline $\begin{array}{l}\text { Unauthorized workers are not permitted to } \\
\text { ride on PITs. }\end{array}$ & $\square$ & $\square$ & $\square$ & \\
\hline $\begin{array}{l}\text { Operators are prohibited from driving up to } \\
\text { anyone standing in front of a fixed object. }\end{array}$ & $\square$ & $\square$ & $\square$ & \\
\hline $\begin{array}{l}\text { Arms and legs are not placed between the } \\
\text { uprights of the mast or outside the running } \\
\text { lines of the PIT. }\end{array}$ & $\square$ & $\square$ & $\square$ & \\
\hline $\begin{array}{l}\text { Loads handled do not exceed the rated } \\
\text { capacity of the PIT. }\end{array}$ & $\square$ & $\square$ & $\square$ & \\
\hline $\begin{array}{l}\text { PITs are inspected at the beginning of each } \\
\text { work shift for any safety concerns. }\end{array}$ & $\square$ & $\square$ & $\square$ & \\
\hline $\begin{array}{l}\text { PITs in need of repair are removed from } \\
\text { service immediately. }\end{array}$ & $\square$ & $\square$ & $\square$ & \\
\hline $\begin{array}{l}\text { Fuel tanks are not filled while the engine } \\
\text { is running. }\end{array}$ & $\square$ & $\square$ & $\square$ & \\
\hline $\begin{array}{l}\text { PITs are operated and maintained such that } \\
\text { harmful concentrations of dangerous gases } \\
\text { or fumes do not occur. }\end{array}$ & $\square$ & $\square$ & $\square$ & \\
\hline $\begin{array}{l}\text { PITs have a warning horn, whistle, gong, or } \\
\text { other device that can be clearly heard above } \\
\text { normal noise in the areas where it is operated. }\end{array}$ & $\square$ & $\square$ & $\square$ & \\
\hline
\end{tabular}

\section{Additional Resources}

- OSHA Regulations: 29 CFR 1910.178, Powered Industrial Trucks

- OSHA: Powered Industrial Trucks - Forklifts 


\section{Medical Services and First Aid}

\begin{tabular}{|c|c|c|c|c|}
\hline Medical Services and First Aid & Yes & No & N/A & Comments \\
\hline $\begin{array}{l}\text { A hospital, clinic, or infirmary for medical care } \\
\text { is located near the workplace. }\end{array}$ & $\square$ & $\square$ & $\square$ & \\
\hline $\begin{array}{l}\text { If a medical facility is not located near the } \\
\text { workplace, at least one worker on each shift } \\
\text { is adequately trained and qualified to render } \\
\text { first aid. }\end{array}$ & $\square$ & $\square$ & $\square$ & \\
\hline $\begin{array}{l}\text { Medical personnel are readily available } \\
\text { for advice and consultation on matters of } \\
\text { workers' health. }\end{array}$ & $\square$ & $\square$ & $\square$ & \\
\hline $\begin{array}{l}\text { Fully supplied first aid kits are easily } \\
\text { accessible to each work area, are adequate } \\
\text { for the particular area or operation, and } \\
\text { are periodically inspected and replenished } \\
\text { as needed. }\end{array}$ & $\square$ & $\square$ & $\square$ & \\
\hline $\begin{array}{l}\text { Workers who only render first aid as a } \\
\text { collateral duty are provided with appropriate } \\
\text { PPE, such as gloves. }\end{array}$ & $\square$ & $\square$ & $\square$ & \\
\hline $\begin{array}{l}\text { Workers who are expected to respond } \\
\text { to medical emergencies as part of their } \\
\text { job responsibilities have received first aid } \\
\text { training; had hepatitis B vaccinations made } \\
\text { available to them; had appropriate training on } \\
\text { procedures to protect them from bloodborne } \\
\text { pathogens, including universal precautions; } \\
\text { and have available and understand how to use } \\
\text { appropriate PPE to protect against exposure } \\
\text { to bloodborne diseases. }\end{array}$ & $\square$ & $\square$ & $\square$ & \\
\hline
\end{tabular}




\begin{tabular}{|c|c|c|c|c|}
\hline Medical Services and First Aid & Yes & No & N/A & Comments \\
\hline $\begin{array}{l}\text { Any worker that had an exposure incident } \\
\text { involving bloodborne pathogens, received } \\
\text { an immediate post-exposure confidential } \\
\text { medical evaluation and follow-up. }\end{array}$ & $\square$ & $\square$ & $\square$ & \\
\hline Emergency phone numbers are posted. & $\square$ & $\square$ & $\square$ & \\
\hline
\end{tabular}

\section{Additional Resources}

- OSHA Regulations:

- 29 CFR 1910.151, Medical Services and First Aid

- 29 CFR 1910.1030, Bloodborne Pathogens

- OSHA: Medical and First Aid

- OSHA: Bloodborne Pathogens and Needlestick Prevention

- NIOSH: Bloodborne Infectious Diseases 


\section{Noise Exposure}

\begin{tabular}{|c|c|c|c|c|}
\hline Noise Exposure & Yes & No & N/A & Comments \\
\hline $\begin{array}{l}\text { Areas in the workplace where noise levels } \\
\text { exceed } 85 \text { decibels have been identified } \\
\text { and evaluated. }\end{array}$ & $\square$ & $\square$ & $\square$ & \\
\hline $\begin{array}{l}\text { Noise levels have been measured with a } \\
\text { sound level meter or an octave band analyzer } \\
\text { and records are being kept. }\end{array}$ & $\square$ & $\square$ & $\square$ & \\
\hline $\begin{array}{l}\text { When determined by an evaluation of worker } \\
\text { noise exposure, a hearing conservation } \\
\text { program has been implemented. }\end{array}$ & $\square$ & $\square$ & $\square$ & \\
\hline $\begin{array}{l}\text { An ongoing preventive health program is in } \\
\text { place to educate workers about safe levels } \\
\text { of noise, exposures, effects of noise on their } \\
\text { health, and the use of personal protection. }\end{array}$ & $\square$ & $\square$ & $\square$ & \\
\hline $\begin{array}{l}\text { When workers are subjected to sound } \\
\text { exceeding the levels in } 29 \text { CFR 1910.95, } \\
\text { Table G-16, engineering controls, } \\
\text { administrative control, and/or personnel } \\
\text { protective equipment are used to reduce } \\
\text { the level of sound exposure to be within the } \\
\text { levels of the table. }\end{array}$ & $\square$ & $\square$ & $\square$ & \\
\hline $\begin{array}{l}\text { Approved hearing protective equipment } \\
\text { (noise attenuating devices) is available to } \\
\text { every worker working in noisy areas. }\end{array}$ & $\square$ & $\square$ & $\square$ & \\
\hline $\begin{array}{l}\text { Workers are properly fitted and instructed in } \\
\text { the use of hearing protectors. }\end{array}$ & $\square$ & $\square$ & $\square$ & \\
\hline $\begin{array}{l}\text { Workers in high noise areas are given } \\
\text { periodic audiometric testing to ensure that } \\
\text { the hearing protection system is effective. }\end{array}$ & $\square$ & $\square$ & $\square$ & \\
\hline
\end{tabular}




\begin{tabular}{|c|c|c|c|c|}
\hline Noise Exposure & Yes & No & N/A & Comments \\
\hline $\begin{array}{l}\text { A copy of OSHA's Occupational Noise } \\
\text { Exposure standard is available and posted in } \\
\text { the workplace. }\end{array}$ & $\square$ & $\square$ & $\square$ & \\
\hline $\begin{array}{l}\text { Warning signs are posted where hearing } \\
\text { protection is needed. }\end{array}$ & $\square$ & $\square$ & $\square$ & \\
\hline
\end{tabular}

\section{Additional Resources}

- OSHA Regulations: 29 CFR 1910.95, Occupational Noise Exposure

- OSHA: Occupational Noise Exposure

- NIOSH: Noise and Hearing Loss Prevention

- NIOSH Sound Level Meter App 


\section{Permit-Required Confined Spaces}

\begin{tabular}{|c|c|c|c|c|}
\hline Permit-Required Confined Spaces & Yes & No & N/A & Comments \\
\hline $\begin{array}{l}\text { The workplace has been evaluated and } \\
\text { permit-required confined spaces have } \\
\text { been identified. }\end{array}$ & $\square$ & $\square$ & $\square$ & \\
\hline $\begin{array}{l}\text { Danger signs are posted or other equally } \\
\text { effective means of informing workers is } \\
\text { provided regarding the existence and } \\
\text { location of, and the dangers posed by, the } \\
\text { confined spaces. }\end{array}$ & $\square$ & $\square$ & $\square$ & \\
\hline $\begin{array}{l}\text { A written permit-required confined space } \\
\text { program has been implemented. }\end{array}$ & $\square$ & $\square$ & $\square$ & \\
\hline $\begin{array}{l}\text { Adequate illumination is provided for the } \\
\text { work to be performed in the confined space. }\end{array}$ & $\square$ & $\square$ & $\square$ & \\
\hline $\begin{array}{l}\text { All lines to a confined space that contain } \\
\text { inert, toxic, flammable, or corrosive materials } \\
\text { are valved off and blanked, or disconnected } \\
\text { and separated before entry. }\end{array}$ & $\square$ & $\square$ & $\square$ & \\
\hline $\begin{array}{l}\text { All sources of mechanical energy, including } \\
\text { impellers, agitators, or other moving parts } \\
\text { and equipment inside confined spaces, are } \\
\text { locked out if they present a hazard. }\end{array}$ & $\square$ & $\square$ & $\square$ & \\
\hline $\begin{array}{l}\text { All portable electrical equipment used } \\
\text { inside confined spaces is either grounded } \\
\text { and insulated, or equipped with ground } \\
\text { fault protection. }\end{array}$ & $\square$ & $\square$ & $\square$ & \\
\hline $\begin{array}{l}\text { Before entry, confined spaces are thoroughly } \\
\text { emptied of any decaying vegetation or } \\
\text { animal matter that may produce methane, or } \\
\text { create an oxygen-deficient atmosphere. }\end{array}$ & $\square$ & $\square$ & $\square$ & \\
\hline $\begin{array}{l}\text { Appropriate atmospheric tests are } \\
\text { performed to check for oxygen deficiency, } \\
\text { flammable gases and vapors, and for } \\
\text { potential toxic air contaminants in the } \\
\text { confined space before entry. }\end{array}$ & $\square$ & $\square$ & $\square$ & \\
\hline
\end{tabular}




\begin{tabular}{|c|c|c|c|c|}
\hline Permit-Required Confined Spaces & Yes & No & N/A & Comments \\
\hline $\begin{array}{l}\text { The confined space is checked for } \\
\text { possible industrial waste that could } \\
\text { contain toxic properties. }\end{array}$ & $\square$ & $\square$ & $\square$ & \\
\hline $\begin{array}{l}\text { Either natural or mechanical ventilation is } \\
\text { provided prior to confined space entry. }\end{array}$ & $\square$ & $\square$ & $\square$ & \\
\hline $\begin{array}{l}\text { The atmosphere inside the confined space is } \\
\text { frequently tested or continuously monitored } \\
\text { during work. }\end{array}$ & $\square$ & $\square$ & $\square$ & \\
\hline $\begin{array}{l}\text { When workers are using oxygen-consuming } \\
\text { equipment such as salamanders, torches, } \\
\text { furnaces, etc., in a confined space, sufficient } \\
\text { air is provided to assure combustion without } \\
\text { reducing the oxygen concentration of the } \\
\text { atmosphere below } 19.5 \text { percent by volume. }\end{array}$ & $\square$ & $\square$ & $\square$ & \\
\hline $\begin{array}{l}\text { When combustion-type equipment is used } \\
\text { in a confined space, provisions are made to } \\
\text { ensure the exhaust gases are vented outside } \\
\text { of the enclosure. }\end{array}$ & $\square$ & $\square$ & $\square$ & \\
\hline $\begin{array}{l}\text { If the confined space is below ground and } \\
\text { near areas where motor vehicles operate, } \\
\text { steps are taken to prevent vehicle exhaust or } \\
\text { carbon monoxide entering the space. }\end{array}$ & $\square$ & $\square$ & $\square$ & \\
\hline $\begin{array}{l}\text { Use of approved respiratory equipment is } \\
\text { used if the atmosphere inside the confined } \\
\text { space cannot be made acceptable. }\end{array}$ & $\square$ & $\square$ & $\square$ & \\
\hline $\begin{array}{l}\text { A trained and equipped attendant is } \\
\text { positioned outside the confined space, } \\
\text { whose sole responsibility is to watch } \\
\text { the work in progress, sound an alarm if } \\
\text { necessary, and render assistance. }\end{array}$ & $\square$ & $\square$ & $\square$ & \\
\hline $\begin{array}{l}\text { Operable communications between the } \\
\text { entrant(s) and the attendant is maintained } \\
\text { while workers are in the confined space. }\end{array}$ & $\square$ & $\square$ & $\square$ & \\
\hline
\end{tabular}




\begin{tabular}{|c|c|c|c|c|}
\hline Permit-Required Confined Spaces & Yes & No & N/A & Comments \\
\hline $\begin{array}{l}\text { The attendant is appropriately trained and } \\
\text { equipped to handle an emergency. }\end{array}$ & $\square$ & $\square$ & $\square$ & \\
\hline $\begin{array}{l}\text { A means for quick removal of workers is } \\
\text { provided, in case of an emergency. }\end{array}$ & $\square$ & $\square$ & $\square$ & \\
\hline $\begin{array}{l}\text { In an emergency situation, if there } \\
\text { is any question as to the cause, the } \\
\text { rescue workers have lifelines, retrieval } \\
\text { equipment, and appropriate PPE including } \\
\text { respiratory protection. }\end{array}$ & $\square$ & $\square$ & $\square$ & \\
\hline $\begin{array}{l}\text { Before entry, operable communications with } \\
\text { and availability of rescue services are verified. }\end{array}$ & $\square$ & $\square$ & $\square$ & \\
\hline $\begin{array}{l}\text { Compressed gas cylinders are prohibited } \\
\text { inside confined spaces. }\end{array}$ & $\square$ & $\square$ & $\square$ & \\
\hline $\begin{array}{l}\text { Before gas welding or burning is started in a } \\
\text { confined space, hoses are checked for leaks, } \\
\text { torches are lighted only outside the confined } \\
\text { space, and the confined space is tested for } \\
\text { an explosive atmosphere each time before a } \\
\text { lighted torch is taken into the confined space. }\end{array}$ & $\square$ & $\square$ & $\square$ & \\
\hline
\end{tabular}

\section{Additional Resources}

- OSHA Regulations:

- 29 CFR 1910.146, Permit-required confined spaces

- 29 CFR 1910.252, General requirement, Welding, Cutting, and Brazing

- OSHA: Confined Spaces

- NIOSH: Confined Spaces 


\section{Personal Protective Equipment (PPE)}

\begin{tabular}{|c|c|c|c|c|}
\hline Personal Protective Equipment (PPE) & Yes & No & N/A & Comments \\
\hline $\begin{array}{l}\text { Hazards that require the use of PPE (e.g., } \\
\text { head, eye, face, hand, or foot protection) } \\
\text { have been identified. }\end{array}$ & $\square$ & $\square$ & $\square$ & \\
\hline $\begin{array}{l}\text { For the hazards identified, the appropriate } \\
\text { and properly fitted PPE has been selected to } \\
\text { provide suitable protection from these hazards. }\end{array}$ & $\square$ & $\square$ & $\square$ & \\
\hline Affected workers use the appropriate PPE. & $\square$ & $\square$ & $\square$ & \\
\hline $\begin{array}{l}\text { PPE is provided by the employer, at no cost } \\
\text { to the workers, except as noted in } 29 \text { CFR } \\
\text { 1910.132(h). }\end{array}$ & $\square$ & $\square$ & $\square$ & \\
\hline $\begin{array}{l}\text { Workers have been trained on PPE } \\
\text { procedures, including what PPE is necessary } \\
\text { for job tasks, when it is needed, and how to } \\
\text { properly wear and adjust it. }\end{array}$ & $\square$ & $\square$ & $\square$ & \\
\hline $\begin{array}{l}\text { Appropriate eye or face protection is used } \\
\text { when workers are exposed to hazards such as } \\
\text { flying particles, molten metal, liquid chemicals, } \\
\text { acids or caustic liquids, chemical gases or } \\
\text { vapors, or potentially injurious light radiation. }\end{array}$ & $\square$ & $\square$ & $\square$ & \\
\hline $\begin{array}{l}\text { Workers who wear corrective lenses } \\
\text { (glasses or contacts) in workplaces with } \\
\text { harmful exposures wear eye protection that } \\
\text { incorporates the prescription in its design, or } \\
\text { wear eye protections that fits properly over } \\
\text { the prescription lenses. }\end{array}$ & $\square$ & $\square$ & $\square$ & \\
\hline $\begin{array}{l}\text { Protective eye and face protection devices } \\
\text { comply with the requirements of the } \\
\text { appropriate ANSI standards, or provide } \\
\text { protection that is at least as effective as the } \\
\text { comparable ANSI standard. }\end{array}$ & $\square$ & $\square$ & $\square$ & \\
\hline
\end{tabular}




\begin{tabular}{|c|c|c|c|c|}
\hline Personal Protective Equipment (PPE) & Yes & No & N/A & Comments \\
\hline $\begin{array}{l}\text { Protective gloves, aprons, shields, or other } \\
\text { means are used where workers could be } \\
\text { cut or where there is reasonably anticipated } \\
\text { exposure to corrosive liquids, chemicals, or } \\
\text { blood or other potentially infectious materials. }\end{array}$ & $\square$ & $\square$ & $\square$ & \\
\hline $\begin{array}{l}\text { Hard hats are worn where the danger of } \\
\text { falling objects exists. }\end{array}$ & $\square$ & $\square$ & $\square$ & \\
\hline $\begin{array}{l}\text { Hard hats are periodically inspected for } \\
\text { damage to the shell and suspension system. }\end{array}$ & $\square$ & $\square$ & $\square$ & \\
\hline $\begin{array}{l}\text { Appropriate foot protection is used where } \\
\text { there is the risk of foot injuries from hot, } \\
\text { corrosive, or poisonous substances, falling } \\
\text { objects, crushing, or penetrating actions. }\end{array}$ & $\square$ & $\square$ & $\square$ & \\
\hline $\begin{array}{l}\text { Protection against the effects of } \\
\text { occupational noise is used when sound levels } \\
\text { exceed those of the Occupational Noise } \\
\text { Exposure standard ( } 29 \text { CFR 1910.95). }\end{array}$ & $\square$ & $\square$ & $\square$ & \\
\hline $\begin{array}{l}\text { PPE is maintained in a sanitary condition and } \\
\text { ready for use. }\end{array}$ & $\square$ & $\square$ & $\square$ & \\
\hline $\begin{array}{l}\text { Appropriate procedures are in place } \\
\text { to dispose of or decontaminate PPE } \\
\text { contaminated with, or reasonably anticipated } \\
\text { to be contaminated with, blood or other } \\
\text { potentially infectious materials. }\end{array}$ & $\square$ & $\square$ & $\square$ & \\
\hline
\end{tabular}

\section{Additional Resources}

- OSHA Regulations:

- 29 CFR 1910.132, PPE General Requirements

- 29 CFR 1910.133, Eye and Face Protection

- 29 CFR 1910.135, Head Protection

- 29 CFR 1910.136, Foot Protection

- 29 CFR 1910.137, Electrical Protective Equipment

- 29 CFR 1910.138, Hand Protection
- OSHA: Personal Protective Equipment

- OSHA: Eye and Face Protection

- NIOSH: Personal Protective Equipment

- NIOSH: Protective Clothing and Ensembles

- NIOSH: Eye Safety 


\section{Respiratory Protection}

\begin{tabular}{|c|c|c|c|c|}
\hline Respiratory Protection & Yes & No & N/A & Comments \\
\hline $\begin{array}{l}\text { To the extent feasible, engineering } \\
\text { controls are used to prevent atmospheric } \\
\text { contamination in the workplace. }\end{array}$ & $\square$ & $\square$ & $\square$ & \\
\hline $\begin{array}{l}\text { Hazards that require the use of respiratory } \\
\text { protection have been identified. }\end{array}$ & $\square$ & $\square$ & $\square$ & \\
\hline $\begin{array}{l}\text { Appropriate respirators are provided for } \\
\text { worker use. }\end{array}$ & $\square$ & $\square$ & $\square$ & \\
\hline $\begin{array}{l}\text { A written respiratory protection program } \\
\text { has been established and implemented } \\
\text { in accordance with the requirements of } \\
29 \text { CFR } 1910.134 \text { (c). }\end{array}$ & $\square$ & $\square$ & $\square$ & \\
\hline $\begin{array}{l}\text { The written respiratory protection program } \\
\text { provides workers with worksite-specific } \\
\text { procedures for: selecting respirators; proper } \\
\text { use of respirators in routine and reasonably } \\
\text { foreseeable emergencies situations; and } \\
\text { cleaning, disinfecting, storing, inspecting, } \\
\text { repairing, discarding, and otherwise } \\
\text { maintaining respirators. }\end{array}$ & $\square$ & $\square$ & $\square$ & \\
\hline $\begin{array}{l}\text { As part of the respiratory protection } \\
\text { program, workers are trained on the correct } \\
\text { usage and limitations of the respirators. }\end{array}$ & $\square$ & $\square$ & $\square$ & \\
\hline $\begin{array}{l}\text { Respirators are National Institute for } \\
\text { Occupational Safety and Health (NIOSH)- } \\
\text { approved for the particular application. }\end{array}$ & $\square$ & $\square$ & $\square$ & \\
\hline $\begin{array}{l}\text { Respirators are regularly inspected, cleaned, } \\
\text { sanitized and maintained. }\end{array}$ & $\square$ & $\square$ & $\square$ & \\
\hline $\begin{array}{l}\text { Before workers first use, or are fit-tested for, a } \\
\text { respirator, they receive a medical evaluation } \\
\text { in accordance with } 29 \text { CFR } 1910.134(e) \text {. }\end{array}$ & $\square$ & $\square$ & $\square$ & \\
\hline
\end{tabular}




\begin{tabular}{|c|c|c|c|c|}
\hline Respiratory Protection & Yes & No & N/A & Comments \\
\hline $\begin{array}{l}\text { Workers designated to wear tight-fitting } \\
\text { respirators are fit-tested before their first use } \\
\text { of a respirator and at least annually thereafter. }\end{array}$ & $\square$ & $\square$ & $\square$ & \\
\hline $\begin{array}{l}\text { Workers are trained in the respiratory hazards } \\
\text { to which they may be exposed. }\end{array}$ & $\square$ & $\square$ & $\square$ & \\
\hline $\begin{array}{l}\text { Workers are trained at least annually in the } \\
\text { proper use of respirators, including putting } \\
\text { on and removing them, any limitations on } \\
\text { their use, and their maintenance. }\end{array}$ & $\square$ & $\square$ & $\square$ & \\
\hline $\begin{array}{l}\text { Respirators are stored in a manner and } \\
\text { location to protect them from damage, } \\
\text { contamination, dust, sunlight, extreme } \\
\text { temperatures, excessive moisture, and } \\
\text { damaging chemicals, and are packed } \\
\text { or stored to prevent deformation of the } \\
\text { facepiece and exhalation valve. }\end{array}$ & $\square$ & $\square$ & $\square$ & \\
\hline $\begin{array}{l}\text { Emergency respirators are kept accessible } \\
\text { to the work area, and the storage location is } \\
\text { marked as containing emergency respirators. }\end{array}$ & $\square$ & $\square$ & $\square$ & \\
\hline
\end{tabular}

\section{Additional Resources}

- OSHA Regulations: 29 CFR 1910.134, Respiratory Protection

- OSHA: Respiratory Protection

- OSHA: Small Entity Compliance Guide - Respiratory Protection Standard

- NIOSH: Respirators 


\section{Walking-Working Surfaces}

\begin{tabular}{|c|c|c|c|c|}
\hline Elevated Surfaces & Yes & No & N/A & Comments \\
\hline $\begin{array}{l}\text { Workers working on surfaces that are } \\
\text { elevated more than } 4 \text { feet ( } 1.2 \text { meters) above } \\
\text { a lower level are protected from falling by } \\
\text { guardrail systems, safety net systems, or } \\
\text { personal fall protection systems. }\end{array}$ & $\square$ & $\square$ & $\square$ & \\
\hline $\begin{array}{l}\text { Toeboards, screens, or guardrail systems are } \\
\text { erected to prevent objects from falling to } \\
\text { lower levels. }\end{array}$ & $\square$ & $\square$ & $\square$ & \\
\hline $\begin{array}{l}\text { Canopy structures are erected under } \\
\text { elevated surfaces and potential falling } \\
\text { objects are kept from the edge or hole, or the } \\
\text { areas where objects could fall are barricaded } \\
\text { and entrance into those areas is prohibited. }\end{array}$ & $\square$ & $\square$ & $\square$ & \\
\hline $\begin{array}{l}\text { Workers exposed to potential falling objects } \\
\text { wear appropriate PPE, such as head protection. }\end{array}$ & $\square$ & $\square$ & $\square$ & \\
\hline $\begin{array}{l}\text { Appropriate headroom is provided } \\
\text { where necessary. }\end{array}$ & $\square$ & $\square$ & $\square$ & \\
\hline $\begin{array}{l}\text { Material on elevated surfaces is piled, stacked, } \\
\text { or racked in a manner to prevent it from } \\
\text { tipping, falling, collapsing, rolling, or spreading. }\end{array}$ & $\square$ & $\square$ & $\square$ & \\
\hline
\end{tabular}

\section{Additional Resources}

- OSHA Regulations:

- 29 CFR 1910.22, General Requirements, for Walking and Working Surfaces

- 29 CFR 1910.28, Duty to Have Fall Protection and Falling Object Protection

- OSHA: Walking-Working Surfaces and Fall Protection 


\begin{tabular}{|c|c|c|c|c|}
\hline Floor Holes and Wall Openings & Yes & No & N/A & Comments \\
\hline $\begin{array}{l}\text { Floor holes are guarded by a cover, a } \\
\text { guardrail, or equivalent on all sides (except } \\
\text { at stairways or ladder entrances). }\end{array}$ & $\square$ & $\square$ & $\square$ & \\
\hline $\begin{array}{l}\text { Toeboards are installed around the edges of } \\
\text { permanent floor holes where persons may } \\
\text { pass below the hole. }\end{array}$ & $\square$ & $\square$ & $\square$ & \\
\hline $\begin{array}{l}\text { Covers including skylight screens, are } \\
\text { able to withstand, without failure, twice } \\
\text { the maximum intended load that may be } \\
\text { imposed on the cover at any one time. }\end{array}$ & $\square$ & $\square$ & $\square$ & \\
\hline $\begin{array}{l}\text { Grates or similar type covers over floor holes, } \\
\text { such as floor drains, are designed to allow } \\
\text { unimpeded foot traffic and rolling equipment. }\end{array}$ & $\square$ & $\square$ & $\square$ & \\
\hline
\end{tabular}

\section{Additional Resources}

- OSHA Regulations:

- 29 CFR 1910.28, Duty to Have Fall Protection and Falling Object Protection

- 29 CFR 1910.29, Fall Protection Systems and Falling Object Protection - Criteria and Practices

- OSHA: Walking-Working Surfaces and Fall Protection 


\begin{tabular}{|c|c|c|c|c|}
\hline Portable Ladders & Yes & No & N/A & Comments \\
\hline $\begin{array}{l}\text { All ladders are maintained in good condition; } \\
\text { joints between steps and side rails are } \\
\text { tight, all hardware and fittings are securely } \\
\text { attached, and moveable parts operating } \\
\text { freely without binding or undue play. }\end{array}$ & $\square$ & $\square$ & $\square$ & \\
\hline $\begin{array}{l}\text { Ladders used on slippery surfaces are } \\
\text { secured and stabilized. }\end{array}$ & $\square$ & $\square$ & $\square$ & \\
\hline $\begin{array}{l}\text { Ladders are not placed in front of } \\
\text { passageways, doorways, or driveways where } \\
\text { they can be displaced by other activities or } \\
\text { traffic unless they are secured to prevent } \\
\text { accidental displacement or are guarded by a } \\
\text { temporary barricade to keep the activities or } \\
\text { traffic away from the ladder. }\end{array}$ & $\square$ & $\square$ & $\square$ & \\
\hline $\begin{array}{l}\text { Ladders are not placed on boxes, barrels, } \\
\text { lifts, or other unstable bases to obtain } \\
\text { additional height. }\end{array}$ & $\square$ & $\square$ & $\square$ & \\
\hline $\begin{array}{l}\text { Workers face the ladder and maintain } \\
\text { three points of contact (two hands and a } \\
\text { foot, or two feet and a hand) on the ladder } \\
\text { when climbing. }\end{array}$ & $\square$ & $\square$ & $\square$ & \\
\hline $\begin{array}{l}\text { Workers do not carry any object or load that } \\
\text { could cause them to lose balance and fall } \\
\text { while climbing the ladder. }\end{array}$ & $\square$ & $\square$ & $\square$ & \\
\hline $\begin{array}{l}\text { Workers do not use ladders that are broken; } \\
\text { have missing steps, rungs, or cleats; broken } \\
\text { side rails; or other faulty equipment. }\end{array}$ & $\square$ & $\square$ & $\square$ & \\
\hline $\begin{array}{l}\text { Workers do not use the top step of ordinary } \\
\text { stepladders as a step. }\end{array}$ & $\square$ & $\square$ & $\square$ & \\
\hline $\begin{array}{l}\text { When portable ladders are used to gain } \\
\text { access to elevated platforms, roofs, etc., the } \\
\text { ladder always extends at least } 3 \text { feet ( } 0.9 \\
\text { meters) above the elevated surface. }\end{array}$ & $\square$ & $\square$ & $\square$ & \\
\hline
\end{tabular}




\begin{tabular}{|c|c|c|c|c|}
\hline Portable Ladders & Yes & No & N/A & Comments \\
\hline $\begin{array}{l}\text { The tops of non-self-supporting ladders are } \\
\text { placed so that both side rails are supported. }\end{array}$ & $\square$ & $\square$ & $\square$ & \\
\hline $\begin{array}{l}\text { Workers secure the base of a portable ladder } \\
\text { to prevent slipping, or otherwise lash or hold } \\
\text { it in place when used on unstable, slanted, or } \\
\text { uneven surfaces. }\end{array}$ & $\square$ & $\square$ & $\square$ & \\
\hline $\begin{array}{l}\text { Metal ladders are made with } \\
\text { corrosion-resistant materials or } \\
\text { protected against corrosion. }\end{array}$ & $\square$ & $\square$ & $\square$ & \\
\hline $\begin{array}{l}\text { Portable metal ladders are legibly marked with } \\
\text { signs reading "CAUTION - Do Not Use Around } \\
\text { Electrical Equipment" or equivalent wording. }\end{array}$ & $\square$ & $\square$ & $\square$ & \\
\hline $\begin{array}{l}\text { Workers do not use ladders as guys, braces, } \\
\text { skids, gin poles, or for other than their } \\
\text { intended purposes. }\end{array}$ & $\square$ & $\square$ & $\square$ & \\
\hline $\begin{array}{l}\text { Workers adjust extension ladders while } \\
\text { standing at the base and not while standing on } \\
\text { the ladder or from a position above the ladder. }\end{array}$ & $\square$ & $\square$ & $\square$ & \\
\hline All ladders are routinely inspected for damage. & $\square$ & $\square$ & $\square$ & \\
\hline $\begin{array}{l}\text { Ladders with structural or other defects are } \\
\text { immediately tagged "Dangerous: Do Not } \\
\text { Use" or with similar language and removed } \\
\text { from service until repaired or replaced. }\end{array}$ & $\square$ & $\square$ & $\square$ & \\
\hline $\begin{array}{l}\text { Steps on step stools; and ladder rungs, steps } \\
\text { and cleats, are equally spaced at distances } \\
\text { required by } 29 \text { CFR } 1910.23 \text { (b). }\end{array}$ & $\square$ & $\square$ & $\square$ & \\
\hline
\end{tabular}

\section{Additional Resources}

- OSHA Regulations: 29 CFR 1910.23, Ladders

- OSHA: Portable Ladder Safety QuickCard

- NIOSH - Ladder Safety App 


\begin{tabular}{|c|c|c|c|c|}
\hline Stairs and Stairways & Yes & No & N/A & Comments \\
\hline $\begin{array}{l}\text { Stair rail systems and handrails are provided } \\
\text { on all stairways having at least four risers. }\end{array}$ & $\square$ & $\square$ & $\square$ & \\
\hline $\begin{array}{l}\text { Standard stairs are at least } 22 \text { inches } \\
\text { ( } 56 \text { centimeters) wide. }\end{array}$ & $\square$ & $\square$ & $\square$ & \\
\hline $\begin{array}{l}\text { Standard stairs are angled between } 50 \text { and } \\
30 \text { degrees. }\end{array}$ & $\square$ & $\square$ & $\square$ & \\
\hline $\begin{array}{l}\text { Stair riser heights and tread depths are } \\
\text { uniform between landings. }\end{array}$ & $\square$ & $\square$ & $\square$ & \\
\hline Steps are slip-resistant. & $\square$ & $\square$ & $\square$ & \\
\hline $\begin{array}{l}\text { Stairway handrails are located between } \\
30 \text { inches ( } 76 \text { centimeters) and } 38 \text { inches } \\
\text { (97 centimeters) above the leading edge } \\
\text { of stair treads. }\end{array}$ & $\square$ & $\square$ & $\square$ & \\
\hline $\begin{array}{l}\text { Stairway handrails have at least } 2.25 \text { inches } \\
\text { ( } 5.7 \text { centimeters) of clearance between the } \\
\text { handrails and any other object, including the } \\
\text { wall or surface they are mounted on. }\end{array}$ & $\square$ & $\square$ & $\square$ & \\
\hline $\begin{array}{l}\text { The swing of doors or gates opening directly } \\
\text { on a stairway platform does not reduce the } \\
\text { effective usable depth of the platform to: less } \\
\text { than } 20 \text { inches ( } 51 \text { centimeters) if the platform } \\
\text { was installed prior to January } 17,2017 \text {, or } \\
22 \text { inches ( } 56 \text { centimeters) if the platform } \\
\text { was installed on or after January } 17,2017 \text {. }\end{array}$ & $\square$ & $\square$ & $\square$ & \\
\hline $\begin{array}{l}\text { Stairway handrails are capable of } \\
\text { withstanding a load of } 200 \text { pounds } \\
\text { ( } 890 \text { Newtons), applied within } 2 \text { inches } \\
\text { (5.1 centimeters) of the top edge in any } \\
\text { downward or outward direction. }\end{array}$ & $\square$ & $\square$ & $\square$ & \\
\hline $\begin{array}{l}\text { Stairway landings and platforms are at least } \\
\text { equal to the width of the stairway and at } \\
\text { least } 30 \text { inches ( } 76 \text { centimeters) in depth, as } \\
\text { measured in the direction of travel. }\end{array}$ & $\square$ & $\square$ & $\square$ & \\
\hline
\end{tabular}

\section{Additional Resources}

- OSHA Regulations: 29 CFR 1910.25, Stairways 


\begin{tabular}{|c|c|c|c|c|}
\hline Walkways & Yes & No & N/A & Comments \\
\hline $\begin{array}{l}\text { Walking-working surfaces (any horizontal or } \\
\text { vertical surface on or through which a worker } \\
\text { walks, works, or gains access to a work area } \\
\text { or workplace location) are kept clean, orderly, } \\
\text { and in a sanitary condition. }\end{array}$ & $\square$ & $\square$ & $\square$ & \\
\hline $\begin{array}{l}\text { Wet surfaces are covered with non-slip } \\
\text { materials or where wet processes are used, } \\
\text { drainage is maintained and where feasible, } \\
\text { false floors, platforms, and mats are provided. }\end{array}$ & $\square$ & $\square$ & $\square$ & \\
\hline $\begin{array}{l}\text { Holes in the floor, sidewalk, and other } \\
\text { walking-working surfaces are repaired } \\
\text { properly, covered, and otherwise made safe. }\end{array}$ & $\square$ & $\square$ & $\square$ & \\
\hline $\begin{array}{l}\text { Material and equipment is stored in such } \\
\text { a way that projections do not interfere } \\
\text { with walkways. }\end{array}$ & $\square$ & $\square$ & $\square$ & \\
\hline Spilled materials are cleaned up immediately. & $\square$ & $\square$ & $\square$ & \\
\hline $\begin{array}{l}\text { Aisles and walkways that pass near moving or } \\
\text { operating machinery, welding operations, and } \\
\text { similar operations are arranged so workers are } \\
\text { not subjected to potential hazards. }\end{array}$ & $\square$ & $\square$ & $\square$ & \\
\hline $\begin{array}{l}\text { Adequate headroom is provided for the entire } \\
\text { length of aisles, walkways, and stairways. }\end{array}$ & $\square$ & $\square$ & $\square$ & \\
\hline $\begin{array}{l}\text { Guardrails are provided wherever aisle, } \\
\text { walkway, and stairway surfaces are elevated } \\
\text { more than four feet ( } 1.2 \text { meters) above any } \\
\text { adjacent floor or the ground. }\end{array}$ & $\square$ & $\square$ & $\square$ & \\
\hline $\begin{array}{l}\text { Walking-working surfaces are inspected } \\
\text { regularly and maintained in a safe condition. }\end{array}$ & $\square$ & $\square$ & $\square$ & \\
\hline
\end{tabular}




\begin{tabular}{|c|c|c|c|c|}
\hline Walkways & Yes & No & N/A & Comments \\
\hline $\begin{array}{l}\text { Hazardous conditions on walking-working } \\
\text { surfaces are corrected or repaired before } \\
\text { workers use the surface again. }\end{array}$ & $\square$ & $\square$ & $\square$ & \\
\hline $\begin{array}{l}\text { Workers are provided with a safe } \\
\text { means of access to and egress from } \\
\text { walking-working surfaces. }\end{array}$ & $\square$ & $\square$ & $\square$ & \\
\hline
\end{tabular}

\section{Additional Resources}

- OSHA Regulations:

- 29 CFR 1910.22, General Requirements for Walking and Working Surfaces

- 29 CFR 1910.25, Stairways

- 29 CFR 1910.28, Duty to Have Fall Protection and Falling Object Protection

- OSHA: Walking-Working Surfaces and Fall Protection 


\section{Welding, Cutting, and Brazing}

\begin{tabular}{|c|c|c|c|c|}
\hline Welding, Cutting, and Brazing & Yes & No & N/A & Comments \\
\hline $\begin{array}{l}\text { Only authorized and trained workers are } \\
\text { permitted to use welding, cutting, and } \\
\text { brazing equipment. }\end{array}$ & $\square$ & $\square$ & $\square$ & \\
\hline $\begin{array}{l}\text { Each worker has a copy of, and follows the } \\
\text { appropriate operating instructions. }\end{array}$ & $\square$ & $\square$ & $\square$ & \\
\hline $\begin{array}{l}\text { Only approved apparatuses (torches, } \\
\text { regulators, pressure reducing valves, acetylene } \\
\text { generators, manifolds, etc.) are used. }\end{array}$ & $\square$ & $\square$ & $\square$ & \\
\hline $\begin{array}{l}\text { Precautions are taken to prevent the mixture } \\
\text { of air or oxygen with flammable gases, } \\
\text { except at a burner or in a standard torch. }\end{array}$ & $\square$ & $\square$ & $\square$ & \\
\hline $\begin{array}{l}\text { Fuel gas and oxygen gas cylinders, } \\
\text { cylinder valves, couplings, regulators, hoses, } \\
\text { and apparatuses are kept free of oily or } \\
\text { greasy substances. }\end{array}$ & $\square$ & $\square$ & $\square$ & \\
\hline $\begin{array}{l}\text { Cylinders are stored in assigned locations } \\
\text { away from sources of heat, and from } \\
\text { elevators, stairs, and gangways. }\end{array}$ & $\square$ & $\square$ & $\square$ & \\
\hline $\begin{array}{l}\text { Fuel gas cylinders and oxygen cylinders } \\
\text { in storage are separated by a distance of } \\
\text { at least } 20 \text { feet, or by a non-combustible } \\
\text { barrier at least } 5 \text { feet ( } 1.5 \mathrm{~m} \text { ) high, having a } \\
\text { fire-resistance rating of at least } 30 \text { minutes. }\end{array}$ & $\square$ & $\square$ & $\square$ & \\
\hline $\begin{array}{l}\text { Regulators are removed and valve-protection } \\
\text { caps put in place before moving cylinders, } \\
\text { unless they are secured on special trucks. }\end{array}$ & $\square$ & $\square$ & $\square$ & \\
\hline
\end{tabular}




\begin{tabular}{|c|c|c|c|c|}
\hline Welding, Cutting, and Brazing & Yes & No & N/A & Comments \\
\hline $\begin{array}{l}\text { Workers are trained to never crack open a fuel } \\
\text { gas cylinder valve near sources of ignition. }\end{array}$ & $\square$ & $\square$ & $\square$ & \\
\hline $\begin{array}{l}\text { Before a regulator is removed, the valve is } \\
\text { closed and gas is released. }\end{array}$ & $\square$ & $\square$ & $\square$ & \\
\hline $\begin{array}{l}\text { Red is used to identify the acetylene (and } \\
\text { other fuel-gas) hose, green is used for the } \\
\text { oxygen hose, and black is used for inert gas } \\
\text { and air hoses. }\end{array}$ & $\square$ & $\square$ & $\square$ & \\
\hline $\begin{array}{l}\text { Pressure-reducing regulators are used } \\
\text { only for the gas and pressures for which } \\
\text { they are intended. } \\
\text { Open circuit (no-load) voltage of arc welding } \\
\text { and cutting machines is as low as possible } \\
\text { and not in excess of the recommended limits. }\end{array}$ & $\square$ & $\square$ & $\square$ & \\
\hline $\begin{array}{l}\text { Grounding of the machine frame and safety } \\
\text { ground connections of portable machines is } \\
\text { checked periodically. }\end{array}$ & $\square$ & $\square$ & $\square$ & \\
\hline $\begin{array}{l}\text { Electrodes are removed from holders when } \\
\text { not in use. }\end{array}$ & $\square$ & $\square$ & $\square$ & \\
\hline $\begin{array}{l}\text { Electric power to the welder is shut off when } \\
\text { no one is in attendance. }\end{array}$ & $\square$ & $\square$ & $\square$ & \\
\hline $\begin{array}{l}\text { Workers do not coil or loop welding } \\
\text { electrode cables around their bodies. }\end{array}$ & $\square$ & $\square$ & $\square$ & \\
\hline $\begin{array}{l}\text { Under wet conditions, automatic controls for } \\
\text { reducing no-load voltage are used. }\end{array}$ & $\square$ & $\square$ & $\square$ & \\
\hline $\begin{array}{l}\text { Wet machines are thoroughly dried and } \\
\text { tested before use. }\end{array}$ & $\square$ & $\square$ & $\square$ & \\
\hline
\end{tabular}




\begin{tabular}{|c|c|c|c|c|}
\hline Welding, Cutting, and Brazing & Yes & No & N/A & Comments \\
\hline $\begin{array}{l}\text { Work and electrode lead cables are } \\
\text { frequently inspected for wear and damage, } \\
\text { and replaced when needed. }\end{array}$ & $\square$ & $\square$ & $\square$ & \\
\hline Cable connectors are adequately insulated. & $\square$ & $\square$ & $\square$ & \\
\hline $\begin{array}{l}\text { Floors are swept clean and combustible } \\
\text { floors are kept wet, covered with damp sand, } \\
\text { or protected by fire-resistant shields. }\end{array}$ & $\square$ & $\square$ & $\square$ & \\
\hline $\begin{array}{l}\text { When the object to be welded cannot } \\
\text { be moved and fire hazards cannot be } \\
\text { removed, shields are used to confine heat, } \\
\text { sparks and slag. }\end{array}$ & $\square$ & $\square$ & $\square$ & \\
\hline $\begin{array}{l}\text { Precautions are taken to protect } \\
\text { combustibles on the other side of metal walls } \\
\text { when welding is underway. }\end{array}$ & $\square$ & $\square$ & $\square$ & \\
\hline $\begin{array}{l}\text { Fire watchers are assigned when welding or } \\
\text { cutting is performed in locations where a fire } \\
\text { might develop. }\end{array}$ & $\square$ & $\square$ & $\square$ & \\
\hline $\begin{array}{l}\text { Suitable fire extinguishing equipment is } \\
\text { available for immediate use. }\end{array}$ & $\square$ & $\square$ & $\square$ & \\
\hline $\begin{array}{l}\text { Used drums, barrels, tanks and other } \\
\text { containers are thoroughly cleaned of } \\
\text { substances that could explode, ignite, or } \\
\text { produce toxic vapors, before hot work begins. }\end{array}$ & $\square$ & $\square$ & $\square$ & \\
\hline $\begin{array}{l}\text { Adequate ventilation is provided in areas } \\
\text { where welding or cutting is performed. }\end{array}$ & $\square$ & $\square$ & $\square$ & \\
\hline $\begin{array}{l}\text { Oxygen cylinders in storage are separated } \\
\text { from fuel gas cylinders. }\end{array}$ & $\square$ & $\square$ & $\square$ & \\
\hline
\end{tabular}




\begin{tabular}{|c|c|c|c|c|}
\hline Welding, Cutting, and Brazing & Yes & No & N/A & Comments \\
\hline $\begin{array}{l}\text { In areas where fuel gases are used or stored, } \\
\text { signs are posted that read DANGER, NO } \\
\text { SMOKING, MATCHES, OR OPEN LIGHTS, or } \\
\text { the equivalent. }\end{array}$ & $\square$ & $\square$ & $\square$ & \\
\hline $\begin{array}{l}\text { Workers exposed to arc welding rays and } \\
\text { other hazards created by welding, cutting, } \\
\text { or brazing operations are protected with PPE } \\
\text { and protective clothing. }\end{array}$ & $\square$ & $\square$ & $\square$ & \\
\hline $\begin{array}{l}\text { PPE is appropriate for the work being } \\
\text { performed. }\end{array}$ & $\square$ & $\square$ & $\square$ & \\
\hline
\end{tabular}

\section{Additional Resources}

- OSHA Regulations:

- 29 CFR 1910.252, General Requirement, Welding, Cutting, and Brazing

- 29 CFR 1910.253, Oxygen-Fuel Gas Welding and Cutting

- 29 CFR 1910.254, Arc Welding and Cutting

- 29 CFR 1910.255, Resistance Welding

- OSHA: Welding, Cutting, and Brazing

- NIOSH: Welding and Manganese 


\section{Safety and Health Assistance for Small Businesses}

\section{The following are some key workplace safety and health resources for small businesses. For more information, see OSHA's Small Business webpage.}

\section{OSHA Resources}

\section{On-Site Consultation Program}

The OSHA On-Site Consultation Program offers no-cost and confidential occupational safety and health services to small and mediumsized businesses in all 50 states, the District of Columbia, and several U.S. territories, with priority given to high-hazard worksites. Highly trained safety and occupational health professionals (i.e., consultants) from On-Site Consultation programs established within state agencies or universities work with employers to identify safety and health hazards in workplaces and how to fix them. Consultants also advise employers on how to comply with OSHA standards, train and educate workers, and assist with establishing and improving safety and health programs.

Consultation services are voluntary. To take advantage of this resource, employers request a consultation visit from their local Consultation program and determine the scope of the visit. The visit may focus on a single concern at a facility or it may involve a thorough hazard assessment of an entire facility and its operations.
Benefits of working with Consultation programs include:

- better workplace safety and health conditions,

- enhanced morale and welfare, and

- savings related to reductions in injury and illness rates, lost work days, workers' compensation costs, equipment damage, and product losses.

A small business employer may become eligible for another benefit of the On-Site Consultation Program - participation in the Safety and Health Achievement Recognition Program (SHARP). SHARP recognizes small business employers who have used consultation services and operate an exemplary safety and health program. Acceptance into SHARP by OSHA is an achievement that singles out a business as a model for workplace safety and health. A worksite receives a deferral from OSHA or State Plan programmed inspections during the period that its SHARP designation is valid.

If you are a small business employer interested in no-cost, confidential consultation visit by highly trained consultants, or to locate the consultation program in your state, visit OSHA's On-Site Consultation Program webpage or call (800) 3216742 (OSHA). 


\section{Compliance Assistance Specialists}

OSHA Compliance Assistance Specialists in OSHA's field offices around the country inform employers and workers about OSHA standards, give presentations on specific hazards, and provide information on OSHA's compliance assistance resources and cooperative programs. Visit OSHA's Compliance Assistance Specialist webpage or call 1-800-321-OSHA (6742) to contact your local OSHA office.

\section{Standards, Regulations, and the General Duty Clause}

OSHA has four separate sets of standards:

- General Industry (29 Code of Federal Regulations [CFR] 1910)

- Construction (29 CFR 1926)

- Maritime Employment (29 CFR 1915-1919)

- Agriculture (29 CFR 1928)

OSHA also has regulations on posting and other administrative matters in 29 CFR 1903 and on recording and reporting of injuries and illnesses in 29 CFR 1904.

In addition, the OSH Act, in Section 5(a)(1), has a general duty clause, which provides that:

(a) Each employer - (1) shall furnish to each of his employees employment and a place of employment which are free from recognized hazards that are causing or are likely to cause death or serious physical harm to his employees.

A recognized hazard is a danger recognized by the employer's industry or industry in general, by the employer, or by common sense. The general duty clause does not apply if there is an
OSHA standard dealing with the hazard, unless the employer knows that the standard does not adequately address the hazard.

Review the OSHA standards to identify those that apply to your business. Read the introduction to the subpart heading, and then analyze the possible hazards in terms of your workplace, your equipment, your materials, and your workers. For example, if you are engaged in retail trade or service and you do not have compressed gases, flammables, or explosives on your premises, Hazardous Materials (Subpart H) standards do not apply to your business.

If you have any questions in determining whether a standard applies to your workplace, visit the OSHA website or contact the nearest OSHA Area Office or your state On-Site Consultation program. Employers can also read OSHA's standard interpretations, which are letters or memos written in response to questions from the public about how OSHA interprets or enforces some aspect of an OSHA standard or regulation.

\section{Publications and Other Educational Materials}

OSHA has many types of educational materials to help employers and workers find and prevent workplace hazards, including:

- Publications. All OSHA publications are free at www.osha.gov/publications. You can also call 1-800-321-OSHA (6742) to order publications.

- Videos. OSHA videos are available at www.osha.gov/video.

- Safety and Health Topics Pages. OSHA's Safety and Health Topics pages provide regulatory and enforcement information, 
hazard identification and controls, and best practices and other resources to assist employers, workers, and safety and health professionals ensure safer workplaces.

- QuickTakes. Employers and safety and health professionals can sign-up for QuickTakes at www.osha.gov/quicktakes. OSHA's free, twicemonthly online newsletter provides the latest news about OSHA initiatives and resources.

\section{Training Resources}

- Education Centers. The OSHA Training Institute partners with OSHA Training Institute Education Centers at locations throughout the United States to deliver courses on OSHA standards and occupational safety and health topics to thousands of students a year. These OSHA education centers operate in conjunction with universities, colleges, and learning centers to conduct OSHA courses for the private sector and other federal agencies, making safety and health training and education more accessible to those who need it. There are tuition fees for private sector students.

- Outreach Training Program. The OSHA Outreach Training Program is a voluntary program to promote workplace safety and health and to make workers more knowledgeable about workplace hazards and their rights. Through this program, authorized trainers provide 10 - and 30 -hour training programs. Outreach training does not fulfill the training requirements found in OSHA standards. Employers must provide additional training for their workers on specific hazards of their job.

\section{Cooperative Programs}

OSHA offers the following cooperative programs under which businesses, labor groups, and other organizations can work cooperatively with OSHA.

- Strategic Partnerships. Under the OSHA Strategic Partnership Program (OSPP), OSHA partners with employers, workers, professional or trade associations, labor organizations, and other interested stakeholders. OSHA Strategic Partnerships are unique agreements designed to encourage, assist, and recognize partner efforts to eliminate serious hazards and enhance workplace safety and health practices. OSHA Strategic Partnerships establish specific goals, strategies, and performance measures to improve worker safety and health. Most OSHA Strategic Partnerships are based out of local OSHA Area or Regional Offices.

- Alliance Program. The OSHA Alliance Program enables the agency to develop voluntary, collaborative working relationships with organizations that are committed to workplace safety and health. Through the Alliance Program, OSHA works with organizations such as trade and professional associations, labor unions, educational institutions, community and faith-based groups, and government agencies to share information about OSHA's initiative and compliance assistance resources with workers and employers, and educate workers and employers about their rights and responsibilities

- Voluntary Protection Programs (VPP). The OSHA Voluntary Protection Programs (VPP) recognize employers and workers in the private industry and federal agencies who have implemented effective safety and health 
management systems and maintain injury and illness rates below national Bureau of Labor Statistics averages for their respective industries. In VPP, management, labor, and OSHA work cooperatively and proactively to prevent fatalities, injuries, and illnesses through a system focused on: hazard prevention and control; worksite analysis; training; and management commitment and worker involvement. To participate, employers must submit an application to OSHA and undergo a rigorous onsite evaluation by a team of safety and health professionals.

\section{Whistleblower Program: Protection from Retaliation}

To help ensure that workers are free to participate in safety and health activities, Section 11(c) of the OSH Act prohibits any person from firing or in any manner retaliating against any worker for exercising rights under the OSH Act. These rights include raising safety and health concerns with an employer, reporting a work-related injury or illness, filing a complaint with OSHA, seeking an OSHA inspection, participating in an OSHA inspection and participating or testifying in any proceeding related to an OSHA inspection.

Protection from retaliation means that an employer cannot retaliate by taking "adverse action" against workers, such as:

- Firing or laying off

- Demoting

- Denying overtime or promotion

- Disciplining

- Denying benefits

- Failing to hire or rehire

- Intimidation or harassment

- Making threats

- Reassignment to a less desirable position or actions affecting promotion prospects

- Reducing pay or hours
- More subtle actions, such as isolating, ostracizing, mocking, or falsely accusing the employee of poor performance

- Blacklisting (intentionally interfering with an employee's ability to obtain future employment)

- Constructive discharge (quitting when an employer makes working conditions intolerable due to the employee's protected activity)

- Reporting the employee to the police or immigration authorities

Workers who believe an employer has retaliated against them for exercising their safety and health rights should contact their local OSHA office right away. A worker must file a retaliation complaint with OSHA within 30 calendar days from the date the retaliatory decision has been both made and communicated to the worker. No form is needed, but workers must contact OSHA within 30 days of the alleged retaliation. Complaints may be filed verbally with OSHA by visiting or calling the local OSHA office at 1-800-321-OSHA (6742), or may be filed in writing by sending a written complaint by facsimile, electronic communication, hand delivery during normal business hours, U.S. mail, or other third-party commercial carrier to the closest OSHA regional or area office, or by filing a complaint online at www.osha.gov/ whistleblower/WBComplaint. For more information, please visit OSHA's Whistleblower Protection Program webpage.

If a worker believes that working conditions are unsafe or unhealthful, the worker may file a complaint with OSHA concerning a hazardous working condition. The worker may have a legal right to refuse to work if the condition clearly presents a risk of death or serious physical harm, there is not sufficient time for OSHA to inspect, and, where possible, a worker has brought the condition to the attention of the employer. For more information, visit OSHA's Worker Rights webpage. 


\section{State Plans}

State Plans are OSHA-approved workplace safety and health programs operated by individual states or U.S. territories. There are currently 22 State Plans covering both private sector and state and local government workers, and there are six State Plans covering only state and local government workers. OSHA monitors State Plans, which must be at least as effective as OSHA in protecting workers and in preventing work-related injuries, illnesses, and deaths.

If you are in a state with an OSHA-approved State Plan, you may be subject to different or additional requirements, and different or additional cooperative programs may be available to you.

For more information, and to find contact information for your State Plan, see OSHA's State Plans webpage.

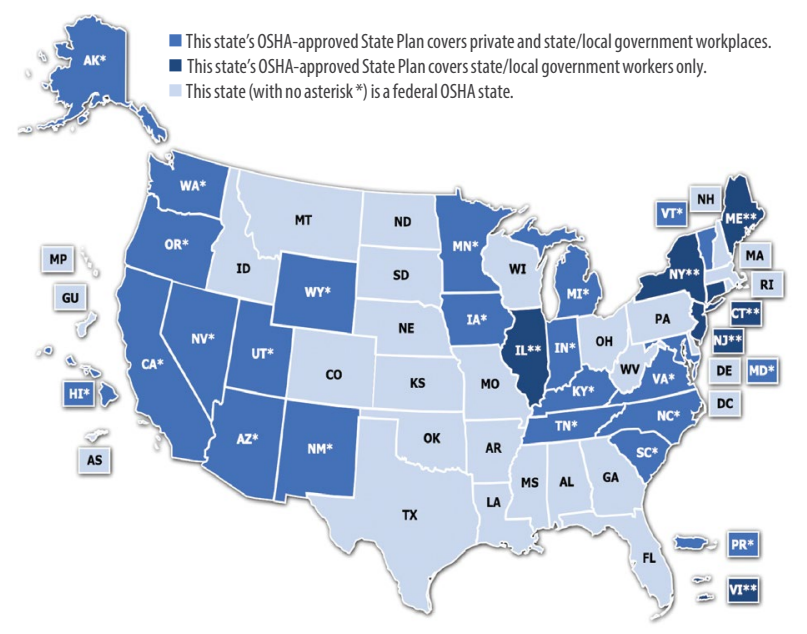

Map of states with OSHA-approved State Plan.

\section{National Institute for Occupational Safety and Health (NIOSH) Resources}

$\mathrm{NIOSH}$ is a research agency focused on the study of worker safety and health, and empowering employers and workers to create safe and healthy workplaces. NIOSH is part of the U.S. Centers for Disease Control and Prevention (CDC), and has the mandate to assure "every man and woman in the Nation safe and healthful working conditions and to preserve our human resources."

Contact NIOSH: 1-800-CDC-INFO or TTY 1-888232-6348,cdcinfo@cdc.gov.

\section{NIOSH Health Hazard Evaluation (HHE) Program}

The NIOSH HHE Program helps employers and employees learn whether health hazards are present at their workplace and recommends ways to reduce hazards and prevent work-related illness. Evaluations are done at no cost.

\section{NIOSH Small Business Resource Guide}

The Small Business Resource Guide provides plans, tools, tips, and information for keeping your workers safe and well while managing time and cost investments.

\section{NIOSH Fatality Assessment and Control Evaluation (FACE) Program}

Through the FACE Program, NIOSH and state partners investigate selected work- related fatalities to identify work situations that pose a high risk of injury. NIOSH and its partners then formulate and disseminate prevention strategies. FACE investigation reports and related NIOSH worker safety and health documents can be accessed at the NIOSH FACE webpage. 


\section{Other Resources}

\section{Workers' Compensation Carriers and Other Insurance Companies}

Many workers' compensation carriers, as well as liability and fire insurance companies, conduct periodic inspections and visits to evaluate safety and health hazards. Managers of small and medium-sized businesses should know what services are available from these sources. Contact your carrier to see what it has to offer.

\section{Trade Associations and Employer Groups}

Many trade associations and employer groups collect and disseminate information on workplace safety and health matters to better serve their members. If you are a member of such a group, find out how it is assisting its members. If you are not a member, find out if these groups are also circulating their materials to nonmembers.

\section{Trade Unions and Employee Groups}

If your workers are organized, set up communications, as you do in normal labor relations, to coordinate action on hazards in your business. Safety and health is one area where advance planning will produce action on common goals. Many trade unions have safety and health expertise that they are willing to share.

\section{Professional Associations}

The following are examples of professional associations that have a broad range of expertise and information on workplace safety and health and have local chapters that small businesses could join.

- National Safety Council

- American Society of Safety Professionals

- American Industrial Hygiene Association

\section{Small Business Development Centers}

The U.S. Small Business Administration (SBA) administers the Small Business Development Center (SBDC) Program to provide management and technical assistance to current and prospective small business owners. Their nearly 1,000 centers across the country have services that include helping small businesses with financial, marketing, production, organization, engineering, and technical problems.

\section{Voluntary Consensus Standards}

Organization such as the American National Standards Institute (ANSI) and National Fire Protection Association (NFPA) issue voluntary consensus standards on various workplace safety and health topics. These are not OSHA standards, but they are developed by organizations through an open and balanced process to reflect current expertise and industry best practices.

\section{The Small Business}

\section{Regulatory Enforcement} Fairness Act of 1996 (SBREFA)

The Small Business Regulatory Enforcement Fairness Act of 1996 (SBREFA) gives small businesses help in understanding and complying with OSHA regulations and allows them a voice in developing new regulations. Under SBREFA, OSHA must:

- Produce Small Entity Compliance Guides for some agency rules;

- Be responsive to small business inquiries about complying with the Agency's regulations;

- Submit final rules to Congress for review;

- Have a penalty reduction policy for small businesses; and

- Involve small businesses in developing proposed rules expected to significantly affect a large number of small entities through Small Business Advocacy Review Panels. 


\section{Commenting on Enforcement Actions}

Under a law passed by Congress in 1996, the Small Business Administration (SBA) has established an SBA Ombudsman and SBA Regulatory Fairness Boards to investigate small business complaints about Federal agency enforcement actions.

If you are a small business and believe that you have been treated unfairly by OSHA, you may file an electronic comment/complaint with the SBA Ombudsman online at: www.sba.gov/ ombudsman. Or you may contact the SBA's Office of the National Ombudsman:

- Toll-free Phone: (888) REG-FAIR (734-3247)

- Fax: (202) 481-5719

- E-mail: ombudsman@sba.gov
- Mail: Office of the National Ombudsman U.S. Small Business Administration 409 3rd Street, S.W., MC2120 Washington, DC 20416

For more information on SBREFA or to view the SBREFA Act in its entirety, visit the webpage: www.sba.gov/advocacy.

NOTE: Filing a complaint with the SBA Ombudsman does not affect any obligation that you may have to comply with an OSHA citation or other enforcement action. Nor does it mean that you need not take other available legal steps to protect your interests.

\section{OSHA Regional Offices}

\section{Region 1}

Boston Regional Office

$\left(C T^{*}, \mathrm{ME}^{*}, \mathrm{MA}, \mathrm{NH}, \mathrm{RI}, \mathrm{VT}^{*}\right)$

JFK Federal Building

25 New Sudbury Street, Room E340

Boston, MA 02203

(617) 565-9860 (617) 565-9827 Fax

\section{Region 2}

New York Regional Office

$\left(\mathrm{NJ}^{*}, \mathrm{NY}^{*}, \mathrm{PR}^{*}, \mathrm{VI}^{*}\right)$

Federal Building

201 Varick Street, Room 670

New York, NY 10014

(212) 337-2378 (212) 337-2371 Fax

\section{Region 3}

Philadelphia Regional Office

(DE, DC, MD*, PA, VA* WV)

The Curtis Center

170 S. Independence Mall West, Suite 740 West

Philadelphia, PA 19106-3309

(215) 861-4900 (215) 861-4904 Fax

\section{Region 4}

Atlanta Regional Office

(AL, FL, GA, KY*, MS, NC ${ }^{*}, \mathrm{SC}^{*}, \mathrm{TN}^{*}$ )

Sam Nunn Atlanta Federal Center

61 Forsyth Street, SW, Room 6T50

Atlanta, GA 30303

(678) 237-0400 (678) 237-0447 Fax

\section{Region 5}

Chicago Regional Office

$\left(\mathrm{IL}^{*}, \mathrm{IN}^{*}, \mathrm{MI}^{*}, \mathrm{MN}^{*}, \mathrm{OH}, \mathrm{Wl}\right)$

John C. Kluczynski Federal Building

230 South Dearborn Street, Room 3244

Chicago, IL 60604

(312) 353-2220 (312) 353-7774 Fax

\section{Region 6}

Dallas Regional Office

(AR, LA, NM*, OK, TX)

A. Maceo Smith Federal Building

525 Griffin Street, Room 602

Dallas, TX 75202

(972) 850-4145 (972) 850-4149 Fax 


\section{Region 7}

Kansas City Regional Office

(IA*, KS, MO, NE)

Two Pershing Square Building

2300 Main Street, Suite 1010

Kansas City, MO 64108-2416

(816) 283-8745 (816) 283-0547 Fax

\section{Region 8}

Denver Regional Office

(CO, MT, ND, SD, UT* ${ }^{*} \mathrm{WY}^{*}$ )

Cesar Chavez Memorial Building

1244 Speer Boulevard, Suite 551

Denver, CO 80204

(720) 264-6550 (720) 264-6585 Fax

\section{Region 9}

San Francisco Regional Office

$\left(A Z^{*}, C A^{*}, H I^{*}, N^{*}\right.$, and American Samoa,

Guam and the Northern Mariana Islands)

San Francisco Federal Building

90 7th Street, Suite 2650

San Francisco, CA 94103

(415) 625-2547 (415) 625-2534 Fax

\section{Region 10}

Seattle Regional Office

(AK*, ID, OR* WA*)

Fifth \& Yesler Tower

300 Fifth Avenue, Suite 1280

Seattle, WA 98104

(206) 757-6700 (206) 757-6705 Fax

*These states and territories operate their own OSHA-approved job safety and health plans and cover state and local government employees as well as private sector employees. The Connecticut, Illinois, Maine, New Jersey, New York and Virgin Islands programs cover public employees only. (Private sector workers in these states are covered by Federal OSHA). States with approved programs must have standards that are identical to, or at least as effective as, the Federal OSHA standards.

Note: To get contact information for OSHA area offices, OSHA-approved state plans and OSHA consultation projects, please visit www.osha.gov or call 1-800-321-OSHA (6742).

\section{Contact OSHA}

Contact your local OSHA office, visit www.osha.gov, or call OSHA (1-800-321-OSHA (6742), TTY 1-877899-5627) to:

- Ask questions

- Get information or advice
- Report an emergency, fatality, inpatient hospitalization, amputation, or loss of an eye

- File a confidential complaint

For a list of different ways to contact OSHA, see www.osha.gov/contactus. 
